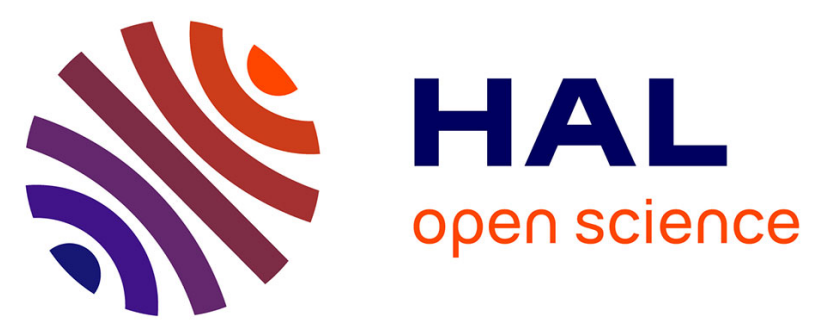

\title{
Purification of tubulin with controlled post-translational modifications by polymerization-depolymerization cycles
}

Judith Souphron, Satish Bodakuntla, A. S Jijumon, Goran Lakisic, Alexis

Gautreau, Carsten Janke, Maria M. Magiera

\section{- To cite this version:}

Judith Souphron, Satish Bodakuntla, A. S Jijumon, Goran Lakisic, Alexis Gautreau, et al.. Purification of tubulin with controlled post-translational modifications by polymerization-depolymerization cycles. Nature Protocols, 2019, 14 (5), pp.1634-1660. 10.1038/s41596-019-0153-7 . hal-02266354

\section{HAL Id: hal-02266354 \\ https://hal.science/hal-02266354}

Submitted on 5 Jul 2021

HAL is a multi-disciplinary open access archive for the deposit and dissemination of scientific research documents, whether they are published or not. The documents may come from teaching and research institutions in France or abroad, or from public or private research centers.
L'archive ouverte pluridisciplinaire $\mathbf{H A L}$, est destinée au dépôt et à la diffusion de documents scientifiques de niveau recherche, publiés ou non, émanant des établissements d'enseignement et de recherche français ou étrangers, des laboratoires publics ou privés. 


\section{Purification of tubulin with controlled posttranslational modifications by polymerization-depolymerization cycles}

Judith Souphron ${ }^{1,2 \#}$, Satish Bodakuntla ${ }^{1,2 \#}$, Jijumon A.S. ${ }^{1,2 \#}$, Goran Lakisic ${ }^{3,4}$, Alexis

Gautreau $^{3}$, Carsten Janke ${ }^{1,2} *$, Maria M. Magiera ${ }^{1,2} *$

${ }^{1}$ Institut Curie, PSL Research University, CNRS UMR3348, F-91405 Orsay, France

${ }^{2}$ Université Paris Sud, Université Paris-Saclay, CNRS UMR3348, F-91405 Orsay, France

${ }^{3}$ Ecole Polytechnique, CNRS UMR7654, Universite Paris-Saclay, F-91120 Palaiseau, France.

${ }^{4}$ present address: Institut MICALIS, AgroParisTech, Université Paris Saclay, INRA, F-78350

Jouy-en-Josas, France

\# equal contribution

*corresponding authors:

Carsten Janke, Institut Curie, PSL Research University, CNRS UMR3348, Centre

Universitaire, Bâtiment 110, F-91405 Orsay, France

Telephone: +33 1 69863127; Fax:+33 1 69863017; Email: Carsten.Janke@curie.fr

Maria M. Magiera, Institut Curie, PSL Research University, CNRS UMR3348, Centre

Universitaire, Bâtiment 110, F-91405 Orsay, France

Telephone: +33 1 69863088; Fax: +33 1 69863017; Email: Maria.Magiera@curie.fr

\section{3 references using the method:}

1. Barisic, M. et al. Microtubule detyrosination guides chromosomes during mitosis. Science 348, 799-803 (2015).

2. Nirschl, J. J., Magiera, M. M., Lazarus, J. E., Janke, C. \& Holzbaur, E. L. F. alpha-Tubulin Tyrosination and CLIP-170 Phosphorylation Regulate the Initiation of Dynein-Driven Transport in Neurons. Cell Rep, celrep 2509 (2016). 
3. Guedes-Dias P, Nirschl JJ, Abreu N, Tokito MK, Janke C, Magiera MM, Holzbaur ELF (2019) Kinesin-3 Responds to Local Microtubule Dynamics to Target Synaptic Cargo Delivery to the Presynapse. Curr Biol 29: 268-282 e268 


\section{Abstract (254)}

In vitro reconstitutions of microtubule assemblies have provided essential mechanistic insights into the molecular bases of microtubule dynamics and their interactions with associated proteins. An emerging regulatory mechanism of microtubule functions is the tubulin code, which suggests that tubulin isotypes and posttranslational modifications play important roles in controlling microtubule functions. To investigate the mechanism of the tubulin code, it is essential to analyse different tubulin variants in vitro. This has so far been difficult, as most reconstitution experiments used heavily posttranslationally modified tubulin purified from brain tissue. Therefore, we developed a protocol that allows purifying tubulin with controlled posttranslational modifications from limited sources using cycles of polymerisation and depolymerisation. While alternative protocols using affinity purification of tubulin yield very pure tubulin as well, our protocol has the unique advantage to select for fully functional tubulin, as non-polymerizable tubulin is excluded in the successive polymerisation cycles. It thus provides a novel routine procedure to obtain tubulin with controlled posttranslational modifications for in vitro reconstitution experiments.

We describe specific protocols for tubulin purification from adherent cells, cells grown in suspension cultures, or from single mouse brains. The protocol can be combined with drug treatment, transfection of cells prior to tubulin purification, or enzymatic treatment during the purification process. The amplification of cells and their growth in spinner bottles takes approximately 13 days; the tubulin purification itself 6-7 hours. The tubulin can be used in TIRF-microscopy-based experiments or pelleting assays to investigate the intrinsic properties of microtubules and their interactions with associated proteins.

\section{Keywords}

Microtubules, tubulin, polymerization, tubulin code, posttranslational modifications, tubulin isotypes, spinner culture, in vitro reconstitution

\section{INTRODUCTION}

Microtubules are essential components of the mammalian cytoskeleton, and are important in almost all key biological processes, such as cell division, cell motility, or cell differentiation (neurons, cilia and flagella, platelets etc.). Owing this importance, one of the key concerns of 
cell biology has been to mechanistically understand how these highly conserved cytoskeletal elements adapt to such a huge variety of biological functions. In vitro experiments aiming at reconstructing microtubule assemblies and functions from purified tubulin and other cytoskeletal components have been instrumental in understanding the biochemical, biophysical and structural properties of microtubules. Tubulin was discovered as the protein building block of microtubules in $1967^{1}$, and soon after it was shown that tubulin can assemble into microtubules in solution ${ }^{2}$. This led to a plethora of studies on the assembly properties and mechanisms of microtubules ${ }^{3,4}$, on how this assembly was regulated by tubulin drugs $^{5}$ and by microtubule-associated proteins (MAPs) ${ }^{6}$. In vitro studies with tubulin have also allowed to propose the mechanism of microtubule dynamic behaviour, such as treadmilling ${ }^{7}$ and dynamic instability ${ }^{8}$.

The development of novel light microscopy techniques ${ }^{9}$ and the growing availability of molecular biology tools for cloning and purifying recombinant proteins led to more and more complex in vitro reconstitutions of microtubule assemblies ${ }^{10}$. This resulted in a large number of amazing discoveries based on in vitro reconstitutions of microtubule assemblies, such as the self-organisation of microtubules and motor proteins ${ }^{11}$, the reconstitution of mitotic spindle functions in minimal systems ${ }^{12,13}$, the analysis of cargo transport with isolated components $^{14}$, or the self-repair of microtubules ${ }^{15}$ to give a few examples.

The reliability of these experiments strongly depends on the biochemical quality of the protein components used for such reconstitution, in particular on high-quality and high-purity tubulin. For the past 50 years, virtually all in vitro reconstitutions were performed with tubulin purified from brain tissue. Brain tubulin can be obtained in large quantities from cow, pig or sheep brain by cycles of warm polymerization and cold depolymerization ${ }^{16}$. This method is highly efficient because of the large abundance of tubulin in brain tissue, and the capacity of tubulin to spontaneously polymerize at high protein concentrations. By cycling several times between polymerized microtubules (warm) and depolymerized soluble tubulin (cold), the method yields highly pure and assembly-competent tubulin, while microtubule aggregates or assembly-incompetent soluble tubulin will be eliminated in the consecutive cycles. The only "contamination" of such-purified tubulin are microtubule-associated proteins (MAPs), which can be removed either by chromatography ${ }^{16}$, or by the polymerization of tubulin in a high-molarity buffer that disrupt the binding of MAPs to the microtubules ${ }^{17}$. The ease of purification of large quantities (gram amounts) of brain tubulin was highly convenient, as none of the alternative methods to purify tubulin from other sources could 
reach the quality, quantity and ease of the brain tubulin preparations. Therefore, brain tubulin is still today the most-used component for in vitro reconstitutions as well as structural studies. This massive use of brain tubulin, however, masks the fact that tubulin is heterogenous in different organisms, cells, and even within single cells (e.g. between cytoplasmic and ciliary microtubules ${ }^{18}$ ). Both, $\alpha$ - and $\beta$-tubulin are expressed from a variety of genes, giving rise to tubulin isotypes, which are further subjected to a large variety of posttranslational modifications (PTMs). Both, specific isotypes and PTMs mark functionally specialized microtubule populations, and might confer specific properties and functions to these microtubules. This concept, known as the "tubulin code"19, is so far little explored, and one of the greatest stumbling stones was the impossibility to purify tubulin with controlled isotypes and PTMs that could replace the brain tubulin - a heterogenous mixture of isotypes particularly enriched in PTMs - in in vitro assays. While a variety of alternative methods have recently emerged, we argued that it will be essential to purify tubulin with controlled PTMs using an approach that is highly similar to the established purification of brain tubulin, the gold standard in the field.

The method we describe here allows to purify tubulin from large and medium scale cultures of mammalian cells by cycles of polymerization and depolymerization. The quality of suchpurified tubulin is equivalent to brain tubulin, as demonstrated in meticulous in vitro reconstitutions ${ }^{20-22}$. The tubulin prepared from Hela S3 cells has been shown to be virtually free of tubulin PTMs, and such nonmodified tubulin can be selectively modified with single $\mathrm{PTMs}^{20}$. This is a huge advantage over brain tubulin, which contains an uncontrollable mixture of PTMs. Our efforts to downscale the purification procedure has also allowed us to set up a small-scale purification of tubulin from single mouse brains ( $\sim 400 \mathrm{mg}$ vs. $\sim 500 \mathrm{~g}$ of a cow brain), which has become a complementary tool to study the functions of tubulin from an emerging plethora of mouse models with altered tubulin PTMs, isotypes, or with mutations in tubulin genes.

\section{COMPARISON WITH OTHER METHODS}

Compared to its blueprint, the tubulin purification from brain tissue, our method is technically more demanding for two reasons: first, the growth of larger amounts of cells needs to be established before the method can be started, and second, the lysis step of the cells and first clarification of this lysate is more meticulous than it is for brain tissue. These technical details 
will be discussed below. Strikingly, a method similar to the here-described has been first used in 1979 to isolate MAPs specific to Hela microtubules ${ }^{23}$, but to our knowledge has never been used to produce tubulin for in vitro reconstitution approaches. There were also several other successful attempts to purify assembly-competent tubulin from different sources in the 1970ies (reviewed in Farrell, 1982 ${ }^{24}$ ), but none of them has been followed up, perhaps due to difficulties in reproducing the cumbersome biochemical procedures.

Alternative methods to purify tubulin without the need of polymerization-depolymerization cycles have also been described. For instance, isotype-specific antibodies were used in immuno-affinity purifications to partially separate tubulin into isotype-enriched fractions ${ }^{25}$. Many alternative protocols are based on pre-absorption of tubulin from cell extracts onto chromatography columns ${ }^{26,27}$. All of these methods require chromatography equipment and specific expertise, which might be the reason they have not been broadly used.

Finally, there were two recent developments that have considerably advanced the purification of tubulin from sources other than brain tissue: the introduction of the TOG-column and purification of recombinant tubulin from insect cells. The TOG column is an affinity matrix based on a domain of the TOG-protein Stup2p from budding yeast. This column uses the affinity of tubulin dimers to the TOG-domain to selectively bind tubulin from cell extracts, and has been shown to produce highly pure fractions of tubulin from many different tissues or cell sources ${ }^{28}$. This method has allowed to purify tubulin from a range of organisms, such as yeast or Caenorhabditis elegans, and study the structure ${ }^{29,30}$ and dynamics ${ }^{31-33}$ of evolutionarily divergent tubulins, or their impact on the behaviour of motor proteins ${ }^{34}$. One of the most significant recent advances was the development of a method to generate recombinant tubulin. This method is based on a bi-cistronic expression of an $\alpha$ - and a $\beta$-tubulin gene in insect cells using the baculo-virus system. Both genes carry a small epitope tag, which allows for a two-step affinity purification of dimers exclusively composed of the recombinant $\alpha$ - and $\beta$-tubulin ${ }^{35}$. This method now allows to systematically study the role of different tubulin isotypes ${ }^{30,36,37}$ and tubulin mutations ${ }^{38}$ in vitro, however, it is a cumbersome and time-consuming method to establish and thus only dedicated labs might decide to commit to it.

\section{ADVANTAGES, LIMITATIONS AND APPLICATIONS}


The great advantage of the here-described method is that it allows the rapid production of milligram-amounts of pure, assembly-competent tubulin from cell lines. When using spinner bottles with Hela S3 cells, the method can be run in the background, and requires only a couple of hours per week for cell harvesting and re-inoculation of new spinners, and one day per week if tubulin purification is carried out immediately (alternatively, cells can be stored in lysis buffer at $-80^{\circ} \mathrm{C}$, and a larger-scale purification can be performed after collecting several rounds of spinner cultures). This tubulin can, in a simple and straight-forward step, be converted to detyrosinated tubulin, thus providing already two pure PTM versions ${ }^{20}$.

In combination with the overexpression of specific tubulin-modifying enzymes, our approach can easily be extended to other tubulin PTMs. Finally, our protocol allows fast and efficient purification of tubulin from single mouse brains, which in the light of a growing number of transgenic mouse models with altered tubulin PTMs, isotypes or with tubulin mutations, provides great opportunities to study the impact of these alterations directly in vitro.

A limitation of our system is its restriction to the native tubulin isotype composition of the cell line used for the tubulin purification. However, all cell lines analysed so far express rather 'generic' $\alpha$ - and $\beta$-tubulin isotypes, i.e. isotypes with the high sequence homologies, which makes such tubulin more homogenous than brain tubulin that is composed of a significant amount of the rather divergent $\beta 3$-tubulin (TUBB3) isotype ${ }^{39}$. A second limitation of the heredescribed method is that specific tubulin isotypes, or tubulins carrying particular PTMs, might polymerise less efficiently, or depolymerise less in case they strongly stabilise microtubules. They could therefore be lost, or disproportionally reduced through during the purification. One striking example is polyaminated tubulin, which is completely excluded in the brain tubulin purification procedure ${ }^{40}$. However, we have shown that the currently most-studied tubulin modifications, such as acetylation, detyrosination, glutamylation and glycylation, are preserved throughout our protocol (see Fig. 4b-d). Thus, while for quantitative studies of tubulin modifications or isotype composition the TOG-column should be the method of choice $^{28}$, our protocol is appropriate for meticulous in vitro reconstructions in which the high purity and assembly competence of tubulin are key ${ }^{20-22}$.

Our method could fully replace the standard brain tubulin preparation, allowing to use tubulin free of PTMs and assembled from less divergent tubulin isotypes on a daily basis. A typical 4-1 spinner culture of Hela S3 cells yields $\sim 15 \mathrm{~g}$ of cells, which in our hand gave rise to $\sim 2 \mathrm{mg}$ of tubulin (corresponding to a yield of $\sim 135 \mu \mathrm{g} / \mathrm{g}$ ). This is lower than the yield from adherent cells, which was rather $\sim 200 \mu \mathrm{g} / \mathrm{g}$, however, growing cells on plastic dishes is more time- 
consuming, and especially their harvest is more cumbersome. We found that ten $15-\mathrm{cm}$ dishes are the maximum number of dishes that can be handled, which gives rise to $\sim 1.2 \mathrm{~g}$ of cells, yielding $\sim 250 \mu \mathrm{g}$ of pure tubulin. The lower yield of cells in suspension culture could be related to a less complex microtubule cytoskeleton in these spherical cells, however this is not a major concern, as spinner cultures are effortlessly grown in large quantities. Overall, cycling of tubulin is bound to engender some loss, which is why it is not surprising that Widlund et al. ${ }^{28}$ report three times higher tubulin yields $(\sim 460 \mu \mathrm{g} / \mathrm{g})$ from human cells using the TOGcolumn.

Finally, our protocol yields $\sim 1 \mathrm{mg} / \mathrm{g}$ of tubulin from mouse brains, which is higher as compared to standard pig brain that in our hands yield rather $\sim 400 \mu \mathrm{g} / \mathrm{g}$ of tubulin. This is most likely related to the longer post-mortem delay of the pig brains as compared to the instantly available mouse brains. Tubulin purified from single mouse brains can be used to directly test the in vitro behaviour of microtubules from a growing number of mouse models with altered tubulin isotype composition ${ }^{41-43}$, or tubulin PTMs ${ }^{44,45}$.

\section{OVERVIEW OF THE PROCEDURE (Fig. 1)}

Our protocol is composed of three main parts. The first part describes the amplification of sources from which tubulin will be purified (step 1): cell lines cultured either in spinner bottles (step 1.A) or adherently on plastic dishes (step 1.B). It is possible to transfect adherently growing cells with expression plasmids, or treat them with drugs (Box 2). We further describe how tubulin can be purified from a single mouse brain (step 1.C).

The second section of the protocol describes the particularities of lysis of Hela S3 cells (step 2.A), HEK-293 cells (step 2.B), or brain tissue (step 2.C).

The third part describes the tubulin purification process itself. First, cells or tissue is lysed and the lysate is cleared (steps 3 and 4.A for brain extracts, or 4.B for cell extracts). Next, the first polymerisation is performed in low-molarity buffer (steps 7-11), followed by the first depolymerisation step (steps 12-17). Optionally, tubulin can then be enzymatically treated at this point (step 18). Tubulin is then subjected to the second polymerisation (steps 19-23), this time in high-molarity buffer to avoid the binding of MAPs to the polymerised microtubules, and MAP-free microtubules are subsequently depolymerised (steps 24-30). An optional, third cycle of polymerisation (steps 31-35) and depolymerisation (steps 36-43) in low-molarity buffer can be performed. 
We then describe qualitative and quantitative analysis of the purified tubulin (Box 3). We propose quantification by protein band intensity measurements on Coomassie-stained gels, and qualitative analyses using immunoblot with antibodies detecting specific tubulin PTMs.

\section{Experimental design}

The initial difficulties that had to be overcome

When setting up this protocol, one major bottleneck was to polymerise tubulin directly from cell extracts. The most important parameter for this to work is the tubulin concentration in the initial extract. Tubulin is, with $\sim 25 \%$ of the total soluble protein, a major component of brain extracts, while it constitutes only $\sim 3 \%$ in extracts of cell lines ${ }^{46}$. To avoid that tubulin does not polymerize due to the lower concentration in cell extracts, we modified the first polymerization step, which in our protocol is performed at low PIPES molarity. This allows MAPs present in the cell extract to help the first round of microtubule polymerization. The molarity of PIPES is strongly increased in the second round of polymerisation, in which the concentration of tubulin can be adjusted to allow efficient polymerisation at high-molarity conditions.

The first important step is the cell lysis, which should assure that most of the cellular microtubules depolymerise into soluble tubulin. To ensure this, the procedure is carried out at $4^{\circ} \mathrm{C}$, which promotes microtubule depolymerisation. Secondly, we found that different cell types and tissues require different lysis techniques. While brain tissue is best lysed using an Ultra-Turrax ${ }^{\circledR}$ homogeniser, HEK-293 cells should be disrupted by repetitive pipetting through a narrow pipette tip. Hela S3 cells and other tested cell types, in contrast, need a more severe disruption procedure. Large amounts grown in spinner cultures are thus lysed using a French press, or an equivalent cell disrupting apparatus, and small amounts by gentle sonication.

An unexpected problem was the difficulty to completely clarify the first extract from lysed cells by ultracentrifugation. We encountered substantial problems with a floating layer that easily contaminates the clear supernatant, but cannot be avoided. We thus chose to carefully remove the clear supernatant between this floating layer and the pellet, even if there is some loss of cell extract at this step. We introduced an additional low-speed centrifugation step to further clarify the first supernatant. This problem varies between different cell types, and can lead to complete failure of the purification procedure if too much floating material is included 
in the first polymerization step. Careful handling is therefore of key importance at this first step.

\section{Upscaling the tubulin production in spinner cultures}

While our method also works for relatively small amounts of adherently growing cells, spinner cultures to grow cells in suspension are primordial in order to obtain milligramamounts of tubulin. The setup we propose here allows growing $4 \times 11$ of suspension cultures in parallel, which yields $\sim 15 \mathrm{ml}$ of cell pellet every 7 days, allowing for the purification of $\sim 2 \mathrm{mg}$ of tubulin. We can also purify tubulin from two spinner bottles, but not less, as at lower amounts the procedure became unreliable. Hela S3 cells $\left(\mathrm{ATCC}^{\circledR} \mathrm{CCL}^{\circledR} 2.2^{\mathrm{TM}}\right)$ which have been optimised for growth in suspension, do not agglutinate and can thus be grown, harvested and in parallel be re-diluted for several weeks or months, without preparing new adherent pre-cultures. Other cells, such as HEK-293, have the tendency to form cell aggregates during growth in suspension, which makes it necessary to inoculate them each time from an adhered pre-culture, which is more time-consuming and work-intense. The advantage of HEK-293 cells is the ease of generating stable, inducible cell lines with the FlpIn $^{\text {TM }}$ T-REx ${ }^{\mathrm{TM}} 293$ cell line (Thermo Fisher \# R78007).

\section{Using a variety of cell and tissue sources to generate custom-modified tubulin}

Smaller amounts of tubulin can also be purified from adherently growing cells. The advantage of this approach is that it allows to use any cell line, treat the cells prior to tubulin isolation, e.g. by transfecting expression vectors to express tubulin-modifying enzymes, tubulin isotypes, or to treat cells with drugs, all of which would be difficult to impossible in cells growing in suspension culture. Another advantage is that specific equipment, such as spinner bottles, is not needed. The drawback is that only small amounts of tubulin can be produced ( $\sim 250 \mu \mathrm{g}$ for ten $15-\mathrm{cm}$ dishes), and that the method is less easily reproducible, as small variations in cell numbers, or delays during the cell harvest can have a strong impact on the efficiency of tubulin polymerization, and thus on the yield. So far, we successfully prepared tubulin from Hela, U-2 OS, and HEK-293 cell lines.

Having downscaled the protocol to very small volumes, it now obviously allows isolating tubulin from very small amounts of brain tissue, i.e. from single brains of transgenic mice. 


\section{REAGENTS:}

PBS (Life Technologies \#14190169)

DMEM medium (Life Technologies \#41965062)

Fetal bovine serum (FBS; Sigma \#F7524)

L-Glutamine (Life Technologies \#25030123)

Penicillin-Streptomycin (Life Technologies \#15140130)

Trichostatin A (TSA; Sigma \#T8552)

jetPEI $^{\circledR}$ (Polyplus \#101)

Carboxypeptidase A (CPA, Sigma C9268, $1.7 \mathrm{U} / \mu \mathrm{l})$

EDTA (Euromedex \#EU0007-C)

Trypsin (Life Technologies \#15090046)

PIPES (Sigma \#P6757) A CRITICAL use this reference

EGTA (Sigma \#E3889)

$1 \mathbf{M} \mathbf{M g C l}_{2}$ (Sigma \#M1028)

Phenylmethanesulfonyl fluoride (PMSF; Sigma \#P7626) ! CAUTION PMSF powder is hazardous. Use skin and eye protection when preparing PMSF solutions.

Isopropanol (VWR \#20842.298)

Aprotinin (Sigma \#A1153)

Leupeptin (Sigma \#L2884)

4-(2-aminoethyl)-benzenesulfonyl fluoride (Sigma \#A8456)

Triton® X-100 (Sigma \#T9284,)

2-mercaptoethanol (Sigma \#M3148) ! CAUTION 2-mercaptoethanol is toxic, manipulate it under a fume hood

GTP (Sigma \#G8877) $\triangle$ CRITICAL use this reference

Glycerol (VWR Chemicals \#24388.295)

KOH (Sigma \#P1767) ! CAUTION KOH is corrosive and causes burns; use eye and skin protection.

Dimethyl sulfoxide (DMSO; Sigma \#D8418) ! CAUTION DMSO can enhance cell and skin permeability of other compounds. Avoid contact and use skin and eye protection.

DTT, DL-Dithiothreitol (Sigma \#D9779)

SDS, Sodium dodecyl sulphate (VWR \#442444H)

Tris (Trizma ${ }^{\circledR}$ base, Sigma \#T1503) 
HCl Hydrochloric acid (VWR \#20252.290)! CAUTION HCl is corrosive and causes burns; use eye and skin protection and work in a chemical fume hood

Bromophenol blue (Sigma \#1.08122)

BSA, Bovine serum albumin (Sigma \#A7906)

Liquid nitrogen ! CAUTION liquid nitrogen causes burns; use eye and skin protection

Ethanol absolute

Anti- $\alpha$-tubulin antibody 12G10 (used at 1/500, Developed by J. Frankel and M. Nelson, obtained from the Developmental Studies Hybridoma Bank, developed under the auspices of the NICHD, and maintained by the University of Iowa)

Anti-detyrosinated tubulin antibody (used at 1/1,000; Merck \#AB3201)

Anti-tyrosinated tubulin antibody YL1/2 (used at 1/1,000; Abcam \#ab6160)

Anti-glutamylated tubulin antibody GT335 (used at 1/20,000; AdipoGen \#AG-20B-0020)

Anti-acetylated tubulin antibody 6-11B-1 (used at 1/2,000; Sigma \#T6793)

Anti-polyglutamylated tubulin antibody polyE (used at 1/20,000; AdipoGen \# AG-25B0030)

Hela S3 cells $\left(\right.$ ATCC $^{\circledR}$ CCL-2.2 ${ }^{\mathrm{TM}}$ ) A CRITICAL STEP: Hela S3 cells have been specifically selected to be able to grow both as adherent and in-suspension cultures.

Flp-In ${ }^{\text {TM }}$ T-REx ${ }^{\text {TM }} 293$ cells (Thermo Fisher \# R78007)

U-2 OS cells (ATCC ${ }^{\circledR}$ HTB-96 $6^{\mathrm{TM}}$ )

Hela cells $\left(\mathrm{ATCC}^{\circledR} \mathrm{CCL}-2^{\mathrm{TM}}\right.$ )

HEK-293 cells (ATCC ${ }^{\circledR}$ CRL-1573TM)

A minimum of one vial of each cell line is necessary to start this protocol. ! CAUTION The cell lines used should be regularly checked to ensure that they are authentic and are not contaminated with mycoplasma.

Mouse brain tissue ! CAUTION Animal care and use for this study were performed in accordance with the recommendations of the European Community (2010/63/UE).

Experimental procedures were specifically approved by the ethics committee of the Institut Curie CEEA-IC \#118 (authorization no. 04395.03 given by National Authority) in compliance with the international guidelines. 


\section{EQUIPMENT:}

1.5- and 2-ml tubes (Eppendorf ${ }^{\circledR} \# 0030125150$ and \#0030120094, respectively)

CRITICAL do not replace original Eppendorf references due to possible differences in material

14-ml round-bottom tubes (Falcon \#352017)

15-ml screw-cap tubes (Falcon \#352095)

50-ml screw-cap tubes (Falcon \#352070)

Ultracentrifuge tubes appropriate for the rotor used: Beckman \#357448 (for TLA-55); \#349622 (for TLA-100.3) and \#355631 (for $70.1 \mathrm{Ti}$ )

5-ml, 10-ml, 25-ml sterile pipettes (Corning \#4487, \#4488 and \#4489, respectively)

Parafilm (Parafilm ${ }^{\circledR}$ M, Bemis North America, USA)

5-ml, 10-ml, 20-ml syringes without needles (Terumo \#SS+05ES1, \#SS+10ES1 and \#SS20ES1, respectively)

Micropestles (an alternative method for brain lysis, Eppendorf \#0030 120.973)

Needles 18G × 11/2" $(1.2 \times 38 \mathrm{~mm}$; Terumo \#18G $)$

Needles 20G × 1 1/2” $(0.9 \times 38 \mathrm{~mm}$; Terumo \#20G $)$

Needles 21G × 4 3/4” $(0.8 \times 120 \mathrm{~mm}, \mathrm{~B}$. Braun \#466 5643)

15-cm-diameter sterile culture dishes (Corning \#430599)

Micro-pipettes p2.5, p10, p20, p100, p200 and p1000 and corresponding tips

Pipette-boy (Drummond Pipette-Aid $\AA$ XP)

Balance $(0.1-10 \mathrm{~g})$ (Sartorius, CPA64S)

pH-meter (Sartorius, Docu-pHmeter)

Vortex mixer (Scientific Industries, Inc. \#SI-0236)

Tabletop centrifuge for $1.5 \mathrm{ml}$ tubes: Eppendorf 5417R (or equivalent)

Laboratory centrifuge for 50-ml tubes: Sigma 4-16 K (or equivalent)

Cell culture hood

Cell culture incubator set at $37^{\circ} \mathrm{C}, 5 \% \mathrm{CO}_{2}$

Inverted microscope (with fluorescence if cell transfection is to be verified)

Biological stirrer Techne MCS-104L installed in the cell culture incubator (for spinner cultures)

1-I cell culture vessels, Techne F7610 (for spinner cultures)

Beckman Avanti J-26 XP centrifuge (for collecting spinner cultures)

JLA-8.1000 rotor (for collecting spinner cultures) 
Beckman 1-I polypropylene bottles (for collecting spinner cultures; Beckman \#355676)

Sonicator (Branson Sonifier 450)

Blender IKA Ultra-Turrax ${ }^{\circledR}$ (for lysing brain tissue)

French pressure cell press (Thermo electron corporation \#FA-078A, with a \#FA-032 cell;

for lysing big amounts of cells)

Ultracentrifuges: Beckman Optima L80-XP (or equivalent), Beckman Optima MAX-XP (or equivalent)

Rotors: Beckman 70.1 Ti; TLA-100.3; and TLA-55 (Beckman \#34218, \#349481 and \#366725)

Water bath equipped with floaters or tube holders

Heating block (Stuart \#SBH130D)

SDS-PAGE electrophoresis equipment (Bio-Rad \#1658001FC) 


\section{REAGENT SETUP:}

\section{Room temperature is $20^{\circ} \mathrm{C}$}

Ethanol 70\% (vol/vol) Mix $700 \mathrm{ml}$ of absolute ethanol and $300 \mathrm{ml}$ of water.

Cell culture medium: 11 DMEM medium supplemented with 10\% (vol/vol; $100 \mathrm{ml}$ ) FBS, $200 \mathrm{mM}(10 \mathrm{ml})$ L-Glutamine, and $1 \times$ Penicillin-Streptomycin $(10 \mathrm{ml})$. Store at $4^{\circ} \mathrm{C}$ and use as long as it is not contaminated.

Trichostatin A 10 mM Dissolve $1 \mathrm{mg}$ of TSA in $330.7 \mu \mathrm{l}$ of DMSO ! CAUTION DMSO can enhance cell and skin permeability of other compounds. Avoid contact and use skin and eye protection.

EDTA, 0.5 M pH 8 Dissolve $36.5 \mathrm{~g}$ of EDTA in water to a final volume of $250 \mathrm{ml}$, adjust to pH 8.0 with $\mathrm{KOH}$ (otherwise EDTA will not dissolve), filter-sterilize or autoclave and store at room temperature indefinitely.

PBS-EDTA, $5 \mathrm{mM}$ Add $5 \mathrm{ml}$ of $0.5 \mathrm{M}$ EDTA to $500 \mathrm{ml}$ of PBS. Store at $4^{\circ} \mathrm{C}$.

PBS-EDTA-TSA, $5 \boldsymbol{\mu M}$ Add $25 \mu 1$ of $10 \mathrm{mM}$ TSA to $50 \mathrm{ml}$ of PBS-EDTA. This solution is used to detach the cells treated with TSA. It should be prepared freshly prior to use.

KOH, $10 \mathrm{M}$ Dissolve $140 \mathrm{~g}$ of $\mathrm{KOH}$ in water to a final volume of $250 \mathrm{ml}$. Store at room temperature indefinitely.

K-PIPES, 0.5 M pH 6.8 Mix 75.5 g of PIPES with water, followed by adding $\mathrm{KOH}$ (otherwise PIPES will not dissolve). Adjust to $\mathrm{pH} 6.8$ with $\mathrm{KOH}$; final volume: $500 \mathrm{ml}$. Filter-sterilize or autoclave and store at $4^{\circ} \mathrm{C}$ for several months.

K-PIPES, 1 M pH 6.8 Mix 15.1 g of PIPES with water, followed by adding $\mathrm{KOH}$ (otherwise PIPES will not dissolve). Adjust to $\mathrm{pH} 6.8$ with $\mathrm{KOH}$; final volume: $50 \mathrm{ml}$. Filter-sterilize or autoclave and store at $4^{\circ} \mathrm{C}$ for several months.

K-EGTA, 0.5 M, pH 7.7 Dissolve $47.5 \mathrm{~g}$ of EGTA in water, adjust to pH 7.7 with $\mathrm{KOH}$; final volume: $250 \mathrm{ml}$. Filter-sterilize and store at room temperature indefinitely.

$\triangle$ CRITICAL STEP None of the buffers used for the tubulin prep should contain sodium salts, always use potassium!

BRB80 Mix $20 \mathrm{ml}$ of $0.5 \mathrm{M}$ PIPES, $40 \mu \mathrm{l}$ of $0.5 \mathrm{M} \mathrm{K}$-EGTA and $20 \mu \mathrm{l}$ of $1 \mathrm{M} \mathrm{MgCl}_{2}$; the final composition is: $80 \mathrm{mM}$ K-PIPES pH 6.8; $1 \mathrm{mM} \mathrm{K-EGTA;} 1 \mathrm{mM} \mathrm{MgCl}$. Filter-sterilize and store at $4{ }^{\circ} \mathrm{C}$ for several months.

PMSF, 0.1 M Dissolve $435 \mathrm{mg}$ of PMSF in a final volume of $25 \mathrm{ml}$ of isopropanol. Store at $-20^{\circ} \mathrm{C}$ for several months. 
Protease inhibitors mix (200× concentrated) Dissolve $4 \mathrm{mg}$ of aprotinin, $10 \mathrm{mg}$ of leupeptin and $10 \mathrm{mg}$ of 4-(2-aminoethyl)-benzenesulfonyl fluoride in $2.5 \mathrm{ml}$ of water, aliquot and store at $-20^{\circ} \mathrm{C}$ for several months.

Triton X-100, 10\% (vol/vol) Mix $5 \mathrm{ml}$ of Triton X-100 with $45 \mathrm{ml}$ of water. Filter-sterilize and store at room temperature indefinitely.

Lysis Buffer Mix $20 \mathrm{ml}$ of BRB80 with $1.5 \mu \mathrm{l}$ of 2-mercaptoethanol, ! CAUTION 2mercaptoethanol is toxic, add it under a fume hood, $200 \mu 1$ of $0.1 \mathrm{M}$ PMSF, $100 \mu 1$ of the protease inhibitors mix ( $200 \times$ concentrated) and, (optional) for HEK-293 cells only, $400 \mu 1$ of $10 \%$ (vol/vol) Triton ${ }^{\circledR} \mathrm{X}-100$. The final concentrations are: $1 \mathrm{mM}$ 2-mercaptoethanol, $1 \mathrm{mM}$ PMSF, $1 \times$ protease inhibitors mix, (optional) $0.2 \%$ Triton $^{\circledR} \mathrm{X}-100$ (vol/vol). Lysis buffer should be prepared freshly prior to use.

GTP, 0.2 M Dissolve $1 \mathrm{~g}$ of GTP in $9.5 \mathrm{ml}$ water, adjust to $\mathrm{pH} 7.5$ with $\mathrm{KOH}$. Aliquot and store at $-20^{\circ} \mathrm{C}$. Avoid repetitive freezing and thawing.

Tris-HCl, 1 M Dissolve $60.56 \mathrm{~g}$ of Tris in $500 \mathrm{ml}$ of water. Adjust the $\mathrm{pH}$ to 6.8 with $\mathrm{HCl}$; filter-sterilize or autoclave the solution and store it at room temperature indefinitely.

Laemmli sample buffer, $5 \times$ For $40 \mathrm{ml}$, heat $16 \mathrm{ml}$ of $1 \mathrm{M}$ Tris-HCl pH 6.8, add $4 \mathrm{~g}$ of SDS and mix gently. Add $2.6 \mathrm{~g}$ DTT and $20 \mathrm{ml}$ (or $24 \mathrm{~g}$ ) of $100 \%$ glycerol. Add $2.5 \mathrm{mg}$ of Bromophenol blue to obtain the right colour intensity. Final concentrations: $450 \mathrm{mM}$ DTT, $10 \%$ SDS, $400 \mu \mathrm{M}$ tris-HCl pH6.8, 50\% glycerol, $\sim 0.006 \%$ (w/vol) bromophenol blue.

Aliquot by desired volumes and store indefinitely at $-20^{\circ} \mathrm{C}$. 


\section{EQUIPMENT SETUP:}

Biological stirrer It should be set inside the cell culture incubator. The rotation speed should be $25 \mathrm{rpm}$ for Hela S3 and HEK-293 cells, it should be empirically determined for other cell types.

Blender Set at power 6 or 7. This should be sufficient to lyse the brain tissue by blending 2-3 times for $10-15 \mathrm{~s}$.

Sonicator We use the probe of $6.5 \mathrm{~mm}$ diameter (Branson \#101-148-070), set at "Output control" 1 , "Duty cycle" $10 \%$ and time depending on the cell type used.

French press We use the French press at medium ratio, and the gauge pressure of 1,000 psi (which corresponds to 3,000 psi inside the disruption chamber).

Ultracentrifuges If two ultracentrifuges are available, one should be set at $4^{\circ} \mathrm{C}$, the other at $30^{\circ} \mathrm{C}$. If only one is available, set it first to $4^{\circ} \mathrm{C}$ and change the temperature during the polymerisation step to $30^{\circ} \mathrm{C}$. It is important to pre-cool or pre-heat the centrifuge before the run, as creating the vacuum before running the samples will make the actual centrifugation start faster.

Rotors If two rotors are available, one should be stored at $4{ }^{\circ} \mathrm{C}$, the other at $30^{\circ} \mathrm{C}$. If only one is available, pre-cool it first to $4^{\circ} \mathrm{C}$ and then heat it to $30^{\circ} \mathrm{C}$ during the polymerisation step. In order to efficiently change the rotor temperature, you can put it in a watertight plastic bag (to avoid wetting), and put either on ice or in the water bath. The temperature of the rotor should always match the temperature of the sample and of the centrifugation step, on one hand to keep the sample in optimal conditions (for example to not depolymerise microtubules by putting a warm sample into a cold rotor), and on the other hand to allow for a faster starting of the centrifuge.

Water bath Should be set to $30^{\circ} \mathrm{C}$. 


\section{PROCEDURE:}

In the procedure, day 0 is used as reference point for the day of the tubulin purification

\section{Sources of tubulin}

1. For growing cells in spinners, follow Option A (Fig. 2). For growing adherent cells, follow Option B. When using mouse brain as a source, follow Option C.

A. Cells grown in spinners TIMING $\sim 10-13$ days depending on the number of spinners

\section{Amplifying the cells (day -13 to -10$)$}

(i) Revive the desired cell type in its preferred medium. Amplify cells to obtain app. $6 \times 10^{7}$ cells (day -13 ).

(ii) Plate those cells on six 15 -cm-diameter dishes at $\sim 10^{7}$ cells per dish. Cells from six $80-90 \%$ confluent $15-\mathrm{cm}$ plates will be needed to inoculate 21 of suspension culture (two spinners). Prepare enough cells to inoculate the desired number of spinners (day -10).

(iii) Add 11 of pre-warmed complete medium to each spinner bottle and incubate on the stirrer table in the cell culture incubator at 20-25 rpm. This step allows for the medium to equilibrate temperature and $\mathrm{pH}$ (day -8).

$\triangle$ CRITICAL STEP To minimize the number of operations, and the risk of contaminations, add all supplements for 11 of complete medium into one of the two 500-ml DMEM bottles, and add this together with the non-supplemented $500 \mathrm{ml}$ DMEM directly into the spinner bottle.

A CRITICAL STEP In order to avoid bacterial or fungal contaminations, thoroughly clean the media bottles and spinner bottles with $70 \%$ ethanol before transferring them into the cell culture hood.

CRITICAL STEP Stir only spinner bottles filled with medium. Stirring empty bottles can result in damage. Slightly open the lateral valves of the spinner bottles to allow the incubator atmosphere to enter the bottle.

\section{Inoculating the spinners (day -7)}

(iv) Remove culture medium from $15-\mathrm{cm}$ plates with cells at $80-90 \%$ confluence (day -7 , Fig. 2a). 
(v) Rinse them very gently with $5 \mathrm{ml}$ PBS (pre-heated to $37^{\circ} \mathrm{C}$ )

$\triangle$ CRITICAL STEP pipette PBS to the border of the dish, check by eye that cells do not detach.

(vi) Soak off all PBS by slightly inclining the culture dish, and removing PBS from the border of the dish.

(vii) Add $2 \mathrm{ml}$ of Trypsin per $15-\mathrm{cm}$ dish, spread it carefully to the entire surface by slightly inclining and turning the dish. Incubate for $3 \mathrm{~min}$ at $37^{\circ} \mathrm{C}$ (for Hela S3 cells), or at room temperature (for HEK-293 cells).

(viii) Add $3 \mathrm{ml}$ of warm, complete medium to the plate to arrest trypsin activity, and detach cells by pipetting the liquid harshly onto the surface of the dish. Observe the detachment of the cell layer by eye. Detach cells from 3 dishes at a time, transfer them to a $15-\mathrm{ml}$ conical-bottom tube, and incubate in the cell culture incubator while detaching the next lot.

(ix) Pellet cells at $250 \times \mathrm{g}$, room temperature, for $5 \mathrm{~min}$.

(x) Re-suspend cells obtained from 3 dishes in $5 \mathrm{ml}$ of fresh complete medium, and mix them well by pipetting up and down to thoroughly separate the cells, but avoiding air bubbles.

$\triangle$ CRITICAL STEP Thorough dissociation of cells at this point is crucial for the optimal growth of cells in suspension. It is particularly important for HEK-293 cells, which tend to form aggregates (Fig. 2b,c). Failure to sufficiently dissociate the cells before inoculation can result in larger cell aggregates with cell death inside the aggregates, and consequently lead to lower tubulin yields.

(xi) Add $5 \mathrm{ml}$ of cell suspension to each spinner bottles containing 11 of pre-equilibrated medium under the cell culture hood, and return them to the stirrer table in the cell culture incubator.

CRITICAL STEP Keep the lateral valves of the spinner bottles slightly open.

(xii) Let cells grow for 1 week, control occasionally for infections or sedimentation due to cell aggregation (Fig. 2b,c).

\section{? TROUBLESHOOTING}

(xiii) (Optional) Treat cells. If stable inducible cell lines are used, or the cells were to be treated with drugs, this should be done $48-24 \mathrm{~h}$ before harvesting (to be optimized for each experiment) (day -2).

\section{Harvesting the cells (day 0)}


(xiv) Verify a slightly orange colour of the culture medium in the spinner bottles. Check the absence of bacterial contamination of each spinner at this point by transferring $0.5 \mathrm{ml}$ of each spinner bottle to one well of a 24-well dish, and observing the samples with an inverted microscope.

(xv) Transfer the cell suspension into 1-1 centrifuge bottles. This step can be carried out in the non-sterile conditions, unless you wish to re-start the spinners straight away (applies only for Hela S3 cells, see the Optional chapter (xvi)).

(xvi) (Optional) To re-inoculate Hela S3 cells for a new culture, leave approximately $100 \mathrm{ml}$ of cell suspension in each spinner bottle, and add 11 of fresh, complete medium. Return the spinners to the stirrer table in the incubator. Do not forget to keep the lateral valves of the spinner bottles slightly open. Continue to (xi).

(xvii) (continued from (xv)) Pellet cells at 250×g, $15 \mathrm{~min}$, room temperature.

(xviii) Re-suspend cells from one centrifuge bottle in $10 \mathrm{ml}$ of ice-cold PBS, then transfer them to the next bottle etc., thus collecting the cells from all the centrifuge bottles and transferring them to a 50-ml screw-cap tube on ice. Repeat the rinsing of the bottles with $10 \mathrm{ml}$ of PBS once or twice, if there are still cells left in the bottles. Pool all the cells in one or two $50 \mathrm{ml}$ tube, fill them to $50 \mathrm{ml}$ with ice-cold PBS if necessary.

(xix) Pellet cells at $250 \times \mathrm{g}, 10 \mathrm{~min}$, at $4^{\circ} \mathrm{C}$. Remove the supernatant.

$\triangle$ CRITICAL STEP During the washing step cell lysis should not occur, but microtubules can already start depolymerising inside the cells. This is why we wash and pellet the cells at $4^{\circ} \mathrm{C}$.

(xx) Determine the volume of the cell pellet and add the same volume of the lysis buffer on cells. Re-suspend the cells in the lysis buffer (the rest of the protocol refers to a hypothetical cell pellet of $10 \mathrm{ml}$, please adjust all measures to the real volume of your cells in each experiment).

$\triangle$ CRITICAL STEP In order to maintain the critical concentration of tubulin in the extract, the volume of the lysis buffer should not exceed the volume of the cell pellet.

PAUSE POINT Once re-suspended in the lysis buffer, cells can be flash-frozen in liquid nitrogen, and stored at $-80^{\circ} \mathrm{C}$ for up to two months.

(xxi) Clean the spinner bottles after use (see Box 1).

\section{Box 1: Cleaning of the spinner bottles}




\section{B. Adherent cells $\odot$ TIMING $\sim 5$ days}

(i) Revive the desired cell type in its preferred medium. Amplify cells to obtain $\sim 10^{8}$ cells (avoid using Hela S3 cells for adherent cell cultures, as their real advantage is to be grown in suspension culture) (day -5).

(ii) Plate all cells on ten 15 -cm-diameter dishes at $\sim 10^{7}$ cells per dish. Cells from minimum ten $80-90 \%$ confluent $15-\mathrm{cm}$ plates will be needed to successfully purify tubulin. (day -3)

\section{Box 2: Treatment of cells (Optional)}

\section{Harvesting the cells (day 0)}

$\triangle$ CRITICAL STEP A rapid cell harvest is very important for the success of the tubulin purification, and should not take more than $15 \mathrm{~min}$ for ten $15-\mathrm{cm}$ dishes. For optimal results, at least the first time this experiment is carried out, three people should participate in this step. Later, one experienced person can handle the rapid detachment of cells.

(iii) Soak medium from the dishes (done by person 1). Remove the medium by sets of three dishes, incline them slightly to facilitate soaking all the medium off.

(iv) Rinse the cell monolayer very gently with $7 \mathrm{ml}$ of PBS-EDTA, then aspirate by inclining the dishes.

(v) Add $5 \mathrm{ml}$ of PBS-EDTA (if cells were treated with TSA (Box 2), they should be detached with PBS-EDTA with $5 \mu \mathrm{M}$ TSA [PBS-EDTA-TSA]), and incubate cells for up to $5 \mathrm{~min}$ at room temperature

$\triangle$ CRITICAL STEP We do not detach cells with trypsin to avoid excessive cell lysis during this step.

(vi) Detach cells from the dishes using a cell lifter (done by person 2). Detach the cells by gently shovelling them towards one place on the dish. Detachment of the cell monolayer is visible with naked eye.

\section{? TROUBLESHOOTING}

(vii) Collect the detached cells in a 50-ml screw-cap tube (done by person 3 ).

(viii) Rinse each plate with $2 \mathrm{ml}$ of PBS-EDTA (or PBS-EDTA-TSA for cells treated with TSA), to collect the remaining cells. 
(ix) Pellet the harvested cells at $250 \times \mathrm{g}, 10 \mathrm{~min}$, at $4^{\circ} \mathrm{C}$. Remove the supernatant.

(x) Determine the volume of the cell pellet, which for ten dishes should be around 1$1.5 \mathrm{ml}$. Add the same volume of the lysis buffer on cells. Re-suspend the cells in the lysis buffer (the rest of the protocol refers to a hypothetical cell pellet of $10 \mathrm{ml}$, please adjust all measures to the real volume of your cells in each experiment).

CRITICAL STEP In order to maintain the critical concentration of tubulin in the extract, the volume of the lysis buffer should not exceed the volume of the cell pellet.

PAUSE POINT Once re-suspended in the lysis buffer, cells can be flash-frozen in liquid nitrogen, and stored at $-80^{\circ} \mathrm{C}$ for up to two months.

\section{Mouse brain $\odot$ TIMING $\sim 15$ min}

(i) Sacrifice the animal by cervical elongation, open the skull with scissors and extract the brain. Wash the brains briefly in the lysis buffer to remove excess blood.

CRITICAL STEP Animal experimentation is subjected to specific legislation in each country, please ensure that you have all necessary permits to work with mice

PAUSE POINT It is possible to snap-freeze brains in liquid nitrogen and store them at $-80^{\circ} \mathrm{C}$ before proceeding to the lysis.

(ii) Add $500 \mu 1$ of the lysis buffer per adult mouse brain in a round-bottom tube.

A CRITICAL STEP Round-bottom tubes are essential for a correct homogenisation of the brain tissue as the probe is too large to reach the tissue in a conical-bottom tube.

\section{Cell and tissue lysis}

For lysis of HEK-293 cells follow Option A (Fig. 2). For lysis of Hela S3, Hela and U-2 OS cells, follow Option B. For lysis of brain tissue, follow Option C.

\section{A. Lysis of HEK-293 cells TIMING $\sim 30 \mathrm{~min}$ (continued from 1.A.(xx) or 1.B.(x))}

(i) Lyse HEK-293 cells by repetitive pipetting up and down through a p1000 tip. Depending on the initial volume of cells, either a 5- or 10-ml pipette with a p1000 tip stuck on the end (Fig. 3b), or directly a p1000 micropipette should be used. The pipetting should be done on ice, for 1 minute every $5 \mathrm{~min}$, for $10 \mathrm{~min}$ ( 3 times). 
(ii) Continue pipetting the solution using a p200 tip stuck on the p1000 tip (Fig. 3b) on ice, for $1 \mathrm{~min}$ every $5 \mathrm{~min}$ for $20 \mathrm{~min}$.

(iii) Take an aliquot of $1 / 100^{\text {th }}$ volume of the lysis mix (L) for analyses (200 $\mu 1$ for $20 \mathrm{ml}$ of L). Add the same volume of Laemmli buffer $2 \times$ and boil for $5 \mathrm{~min}$.

PAUSE POINT then continue to Box 3

\section{B. Lysis of Hela S3, Hela and U-2 OS cells $\odot$ TIMING $\sim 30$ min (continued from 1.A.(xx) or 1.B.(x))}

(i) Lyse Hela S3 cells (from spinner culture) using a French press (set at medium ratio, gauge pressure at 1,000 psi), or an equivalent cell lysis equipment. For adherently grown cells (Hela, U-2 OS), sonicate cells gently, using the $6.5-\mathrm{mm}$ diameter probe, set at "Output control" 1, "Duty cycle" $10 \%$ and for around 45 pulses. Sonicate the cells in a 14-ml round-bottom tube, which has been cut in height to accommodate the probe.

$\triangle$ CRITICAL STEP The sonication should be gentle, to avoid damaging the tubulin, but sufficient to lyse the cells. Check the lysis of the cells every 15 pulses (Fig. 3c).

(ii) Pipette cells through a p200 tip stuck on the p1000 tip (Fig. 3b) on ice, for 1 min every $5 \mathrm{~min}$ for $10 \mathrm{~min}$.

(iii) Take an aliquot of $1 / 100^{\text {th }}$ volume of the lysis mix (L) for analyses (200 $\mu 1$ for $20 \mathrm{ml}$ of L). Add the same volume of Laemmli buffer $2 \times$ and boil for $5 \mathrm{~min}$.

- PAUSE POINT then continue to Box 3

\section{Lysis of brain tissue $\bigcirc I M I N G \sim 30 \mathrm{~min}$}

(i) Homogenize the brains with an Ultra-Turrax blender equipped with a small, $\varnothing \sim 5$-mm probe. The mix should have the colour and consistency of a strawberry milkshake. Alternatively, homogenize brain tissue using a potter homogenizer or a microtube potter, followed by thorough tissue dissociation using rapid pipetting upand-down in a $1-\mathrm{ml}$ syringe with a $18 \mathrm{G}$ needle.

(ii) Take an aliquot of $1 / 100^{\text {th }}$ volume of the lysis mix (L) for analyses $(200 \mu 1$ for $20 \mathrm{ml}$ of L). Add the same volume of Laemmli buffer $2 \times$ and boil for $5 \mathrm{~min}$. 
PAUSE POINT then continue to Box 3

\section{$\underline{\text { Tubulin purification }} \bigcirc$ TIMING $\sim 6 \mathrm{~h}$}

3. Clear lysate by centrifugation at $150,000 \times \mathrm{g}, 4^{\circ} \mathrm{C}, 30 \mathrm{~min}$. Choose adequate tubes and rotors: Beckman \#357448 for volumes up to $1.5 \mathrm{ml}$ (rotor TLA-55), Beckman \#349622 for volumes up to $3.0 \mathrm{ml}$ (rotor TLA-100.3) or Beckman \#355631 for volumes up to $30 \mathrm{ml}$ (rotor $70.1 \mathrm{Ti}$ ). Beckman \#355631 tubes can be centrifuged half-filled, however, for volumes below $10 \mathrm{ml}$, we recommend using several Beckman \#349622 tubes.

\section{4. $\quad$ Removing the supernatant SN1}

\section{For brain extracts, follow Option A. For Cell extracts, follow Option B.}

A.

\section{B. Brain extracts:}

(i) remove supernatant (SN1) with a micropipette of the right volume and proceed to step (iii) or 5.

\section{B. Cell extracts:}

(i) Remove the supernatant gently and without perturbing the floating layer, using a syringe with a needle. For volumes below $4 \mathrm{ml}$ use a $20 \mathrm{G}$ needle on a 5-ml syringe, for higher volumes use the long, $21 \mathrm{G}$ needle on a syringe of appropriate volume. To avoid stirring the solution, remove the supernatant directly when taking tubes out of the centrifuge (instead of carrying them to the bench).

Enter the needle into the supernatant and slowly soak off the liquid by gently moving the needle tip down toward the pellet. As soon as you observe soaking of the floating layer into the syringe, stop. It is important to remove all supernatant at once; going back and forth with the needle leads to rapid contamination of the clear supernatant.

(ii) Record the volume of SN1. For a 10-ml cell pellet, SN1 should be $\sim 12 \mathrm{ml}$.

$\triangle$ CRITICAL STEP Removing clear supernatant is straightforward for brain lysates, from which solid pellets are obtained. It is more difficult for cell extracts, which yield very unsteady pellets, and a floating instable layer of material on the top 
of the supernatant. This material should not be transferred to the next step, as it tends to interfere with the efficiency of tubulin polymerisation.

(iii) (Optional) If despite your efforts, the supernatant is cloudy, transfer it to a 15- or $50-\mathrm{ml}$ tube and centrifuge at $5,000 \times \mathrm{g}, 4^{\circ} \mathrm{C}$ for $10 \mathrm{~min}$ (Fig. 3d).

5. Take an aliquot of $1 / 100^{\text {th }}$ volume of the SN1 or SN1' for analyses ( $120 \mu 1$ for $12 \mathrm{ml}$ of SN1). Add the same volume of Laemmli buffer $2 \times$ and boil for $5 \mathrm{~min}$.

- PAUSE POINT then continue to Box 3

6. Resuspend the pellet P1 in BRB80 (use the same volume as SN1), and keep an aliquot of $1 / 100^{\text {th }}$ of its volume for analyses. Add the same volume of Laemmli buffer $2 \times$ and boil for $5 \mathrm{~min}$. Discard P1.

PAUSE POINT then continue to Box 3

\section{First polymerisation in low-molarity buffer $\bigcirc \mathrm{TIMING} \sim 1 \mathrm{~h}$}

7. Prepare the polymerization mix in a screw-cap tube of appropriate volume:

- SN1 (1 volume, $12 \mathrm{ml}$ )

- $1 / 200^{\text {th }}$ volume of SN1 (60 $\left.\mu 1\right)$ of 0.2-M GTP, final concentration $1 \mathrm{mM}$

- 0.5 volume of SN1 (6 ml) of glycerol (pre-heated to $30^{\circ} \mathrm{C}$, glycerol volume is not considered in calculations, as it is used as a crowding agent)

8. Mix well, avoiding air bubbles, and transfer to one or several ultracentrifuge tubes of the appropriate volume. Equilibrate the weight of tubes in the process (in pairs).

$\triangle$ CRITICAL STEP Proceeding to the polymerisation step directly in centrifuge tubes equilibrated for centrifugation avoids the risk of depolymerising microtubules when pipetting the solution after polymerisation.

9. Cover the tubes with parafilm and transfer them to a $30^{\circ} \mathrm{C}$ water bath. Let polymerise for $20 \mathrm{~min}$.

$\triangle$ CRITICAL STEP In our hands, the efficiency of polymerisation is equivalent at $30^{\circ} \mathrm{C}$ and $37^{\circ} \mathrm{C}$, which is why we opted for $30^{\circ} \mathrm{C}$. We restricted the polymerisation time to $20 \mathrm{~min}$ (max. $30 \mathrm{~min}$ ), as longer incubation did not increase yields.

10. Spin down polymerised microtubules at $150,000 \times \mathrm{g}$, at $30^{\circ} \mathrm{C}$, for $30 \mathrm{~min}$. The pellet P2 (Fig. 3d) contains polymerised microtubules with associated MAPs, as well as other precipitated proteins. The supernatant SN2 contains non-polymerised tubulin and other soluble proteins which do not bind microtubules.

- PAUSE POINT You can freeze the microtubule pellet at $-80^{\circ} \mathrm{C}$ at this point. 


\section{? TROUBLESHOOTING}

11. Take an aliquot of $50 \mu 1$ of the SN2 for analyses. The remaining SN2 can be discarded.. Add $50 \mu$ of Laemmli buffer $2 \times$ and boil for $5 \mathrm{~min}$.

PAUSE POINT then continue to Box 3

\section{First depolymerisation $\odot$ TIMING $\sim 1 \mathrm{~h}$}

12. Transfer the tube with the microtubule pellet on ice, and add $1 / 60^{\text {th }}$ volume of SN1 $(=200 \mu \mathrm{l})$ of ice-cold BRB80, leave on ice for $5 \mathrm{~min}$.

13. Pipette vigorously up and down with a p1000 micropipette to resuspend and depolymerise microtubules. Avoid air bubbles! (Fig. 3d)

14. Continue pipetting up and down with a p200 micropipette until the suspension is homogenous. Leave on ice for 20-30 min, pipet up and down every $5 \mathrm{~min}$.

$\triangle$ CRITICAL STEP The high efficiency of this step is fundamental for the overall yield of the tubulin purification. Give it time and patience it needs.

15. Transfer the tubulin-MAP solution to a 1.5-ml Beckman \#357448 tube. Spin down insoluble components at $150,000 \times \mathrm{g}, 4^{\circ} \mathrm{C}$ for $20 \mathrm{~min}$.

The supernatant SN3 ( 200 $\mu$ l) contains the depolymerised tubulin, MAPs and potentially other soluble proteins. The pellet (P3) contains non-depolymerised microtubules, MAPs, and precipitated proteins. Transfer SN3 to a new 1.5-ml conical tube.

16. Take an aliquot of 1-4 $\mu 1$ of the SN3 for analyses. Add the same volume of Laemmli buffer $2 \times$ and boil for 5 min.

PAUSE POINT then continue to Box 3

17. Resuspend the pellet $\mathrm{P} 3$ in BRB80 (use the same volume as SN3), and keep an aliquot of 1-4 $\mu 1$ for analyses. Add the same volume of Laemmli buffer $2 \times$ and boil for $5 \mathrm{~min}$. The rest of P3 can be discarded.

- PAUSE POINT then continue to Box 3

\section{(Optional) Enzymatic treatment of the tubulin}

18. Incubate $\mathrm{SN} 3(200 \mu \mathrm{l})$ with $1 / 500^{\text {th }}$ ( $\left.\mathrm{vol} / \mathrm{vol} ; 0.4 \mu \mathrm{l} \approx 0.7 \mathrm{U}\right)$ of Carboxypeptidase $\mathrm{A}$ (CPA) for $5 \mathrm{~min}$ at $30^{\circ} \mathrm{C}$ in order to obtain entirely detyrosinated tubulin. 


\section{Second polymerisation in high-molarity buffer $\bigcirc$ TIMING $\sim 1 \mathrm{~h}$}

19. Prepare the high-molarity polymerization mix in a 1.5-ml Beckman \#357448 tube:

- SN3 (1 volume; $200 \mu 1)$

- 1 volume of SN3 $(200 \mu \mathrm{l})$ of $1 \mathrm{M}$ PIPES (pre-heated to $30^{\circ} \mathrm{C}$ ), final concentration $0.5 \mathrm{M}$

$-1 / 100^{\text {th }}$ volume of SN3 (2 $\left.\mu \mathrm{l}\right)$ of $0.2 \mathrm{M} \mathrm{GTP}$, final concentration $1 \mathrm{mM}$

- 1 volume of SN3 $(200 \mu \mathrm{l})$ of glycerol (pre-heated to $30^{\circ} \mathrm{C}$, glycerol volume is not considered in calculations, as it is used as a crowding agent)

20. Mix well, avoiding air bubbles, and transfer to one or several 1.5-ml Beckman \#357448 ultracentrifuge tubes. Pipette precise volumes for rotor equilibration.

$\triangle$ CRITICAL STEP Proceeding to the polymerisation step directly in centrifuge tubes of equilibrated weight avoids the risk of depolymerising microtubules when pipetting the solution after polymerisation.

21. Polymerize for $20 \mathrm{~min}$ in a $30^{\circ} \mathrm{C}$ water bath.

$\triangle$ CRITICAL STEP Longer incubation can lead to depolymerisation of the microtubules and thus lower the yield. Do not exceed $30 \mathrm{~min}$.

22. Sediment polymerised microtubules at $150,000 \times \mathrm{g}, 30^{\circ} \mathrm{C}$ for $30 \mathrm{~min}$.

The pellet $\mathrm{P} 4$ contains polymerised microtubules. The supernatant SN4 contains the MAPs, and small amounts of non-polymerised tubulin and other soluble proteins (Fig. 3d).

PAUSE POINT You can snap-freeze the microtubule pellet at $-80^{\circ} \mathrm{C}$ at this point.

$\triangle$ CRITICAL STEP Remove the supernatant very carefully, in order to eliminate a maximum of MAPs from the microtubule pellet. Note that with each polymerisation cycle the amount of non-polymerising tubulin, as well as non-depolymerisable microtubules decreases.

$\triangle$ CRITICAL STEP SN4 can be conserved at $-80^{\circ} \mathrm{C}$ after snap-freezing for further use of MAPs. As they are in the polymerisation buffer containing high PIPES and glycerol, a buffer exchange is required before further use.

\section{? TROUBLESHOOTING}

23. Take an aliquot of 1-4 $\mu 1$ of the SN4 for analyses. Add the same volume of Laemmli buffer $2 \times$ and boil for $5 \mathrm{~min}$.

PAUSE POINT then continue to Box 3 
Second de-polymerisation $\bigcirc \mathrm{TIMING} \sim 50 \mathrm{~min}$

24. On ice, add $1 / 100^{\text {th }}$ of the initial volume of SN1 $(120 \mu 1$ for SN1=12 ml) of ice-cold BRB80 on the microtubule pellet $\mathrm{P} 4$, leave for $5 \mathrm{~min}$.

25. To resuspend and depolymerise microtubules, pipette up and down with a p200 micropipette. Avoid air bubbles!

26. Continue until the suspension is homogenous. Leave on ice for $20 \mathrm{~min}$, pipet up and down every $5 \mathrm{~min}$.

27. Transfer the tubulin solution to a 1.5-ml Beckman \#357448 tube. Spin down insoluble components at $150,000 \times \mathrm{g}, 4^{\circ} \mathrm{C}$ for $20 \mathrm{~min}$.

28. The supernatant SN5 contains almost exclusively depolymerised tubulin. The pellet P5 (Fig. 3d) contains non-depolymerised microtubules. Transfer SN5 to a new 1.5-ml conical tube.

29. Take an aliquot of 1-4 $\mu 1$ of the SN5 for analyses. Add the same volume of Laemmli buffer $2 \times$ and boil for $5 \mathrm{~min}$.

- PAUSE POINT then continue to Box 3

30. Resuspend the pellet P5 in BRB80 (use the same volume as SN5), and keep an aliquot of 1-4 $\mu$ l for analyses. Add the same volume of Laemmli buffer $2 \times$ and boil for $5 \mathrm{~min}$. The rest of P5 can be discarded.

PAUSE POINT then continue to Box 3

(Optional: can also be performed directly before the use of the tubulin for the actual in vitro experiments)

Third polymerisation in low-molarity buffer and warm spin $\bigcirc$ TIMING $\sim 1 \mathrm{~h}$

31. Prepare the polymerization mix in a 1.5-ml Beckman \#357448 tube:

- SN5 (1 volume, $120 \mu 1)$

$-1 / 200^{\text {th }}$ volume of SN5 $(0.6 \mu 1)$ of GTP $(0.2-\mathrm{M}$ stock solution, final concentration $1 \mathrm{mM}$ )

- 0.5 volume of SN5 (60 $\mu \mathrm{l})$ of glycerol (pre-heated to $30^{\circ} \mathrm{C}$ )

32. Mix well, avoiding air bubbles, and transfer to one or several 1.5-ml Beckman \#357448 ultracentrifuge tubes. Pipette precise volumes for rotor equilibration.

$\triangle$ CRITICAL STEP Proceeding to the polymerisation step directly in centrifuge tubes of equilibrated weight avoids the risk of depolymerising microtubules when pipetting the solution after polymerisation. 
33. Polymerize for $20 \mathrm{~min}$ in a $30^{\circ} \mathrm{C}$ water bath.

$\triangle$ CRITICAL STEP Longer incubation can lead to depolymerisation of the microtubules and thus lower the yield. Do not exceed $30 \mathrm{~min}$.

34. Sediment polymerised microtubules at $150,000 \times \mathrm{g}, 30^{\circ} \mathrm{C}$ for $30 \mathrm{~min}$.

The pellet P6 contains polymerised microtubules. The supernatant SN6 contains small amounts of non-polymerised tubulin.

PAUSE POINT You can freeze the microtubule pellet (P6) at $-80^{\circ} \mathrm{C}$ at this point.

35. Take an aliquot of 1-4 $\mu 1$ of the SN6 for analyses. Add the same volume of Laemmli buffer $2 \times$ and boil for $5 \mathrm{~min}$. The rest of SN6 can be discarded.

PAUSE POINT then continue to Box 3

\section{Third depolymerisation $\bigcirc$ TIMING $\sim 50 \mathrm{~min}$}

36. On ice, add $1 / 100^{\text {th }}$ of the initial volume of SN1 (=120 $\mu$ l for SN1=12 ml) of ice-cold BRB80 onto the microtubule pellet, and incubate for $5 \mathrm{~min}$ on ice.

37. Pipette vigorously up and down with a p200 micropipette to resuspend and depolymerise microtubules. Avoid air bubbles!

38. Continue pipetting up and down with a p20 pipette until the suspension is homogenous. Leave on ice for 20-30 min, pipet up and down every $5 \mathrm{~min}$.

39. Transfer the tubulin solution to a 1.5-ml Beckman \#357448 tube. Spin down insoluble components at $150,000 \times \mathrm{g}, 4^{\circ} \mathrm{C}$ for $20 \mathrm{~min}$. The supernatant SN7 contains pure, depolymerised tubulin. The pellet P7 contains non-depolymerised microtubules. Transfer SN7 to a new $1.5-\mathrm{ml}$ conical tube.

40. Take an aliquot of 1-4 $\mu 1$ of the SN7 for analyses. Add the same volume of Laemmli buffer $2 \times$ and boil for 5 min.

PAUSE POINT then continue to Box 3

41. Quantify protein content of SN7 (see Box 3 for more details).

42. Aliquot into small volumes to avoid future thaw-freeze cycles, snap-freeze in liquid nitrogen and store at $-80^{\circ} \mathrm{C}$ until needed.

43. Resuspend the pellet P7 in BRB80 (use the same volume as SN7), and keep an aliquot of 1-4 $\mu 1$ for analyses. Add the same volume of Laemmli buffer $2 \times$ and boil for $5 \mathrm{~min}$. The rest of P7 can be discarded.

PAUSE POINT then continue to Box 3 


\section{Box 1: Spinner bottle cleaning}

It is important to keep the spinner vessels clean and dry.

1. Once the cells are collected from the spinner bottles, immediately fill them with tap water, to avoid that remaining cells dry and get stuck to the glass.

2. As soon as possible, remove the glass ball and wash it. Rinse spinner bottles thoroughly with water, using a bottle brush if necessary.

$\triangle$ CRITICAL STEP Avoid using detergent, as trace amounts of not-rinsed detergent could hamper the cell growth during the next culture cycle.

3. Re-assemble the spinner with the glass ball, add app $200 \mathrm{ml}$ (or enough to cover the glass ball) of deionised water and autoclave them.

4. Once autoclaved, under a sterile hood remove water from the spinners. Remove the lateral caps completely and open the top cap by tilting it over the edge of the opening. Leave in this position in the open hood for a few hours (or overnight) to dry completely.

$\triangle$ CRITICAL STEP Failure to dry the spinners completely before storing them can result in the rusting of the metal screw that holds the glass ball.

5. Once completely dry, close all the caps, remove from under the hood and store in a secure place. 


\section{Box 2: Treatment of adherently growing cells (optional)}

\section{Transfection with plasmid DNA using the JetPEI ${ }^{\circledR}$ reagent}

(note that Hela S3 cells are very difficult to transfect using the here-described protocol)

1. Seed cells the day before the transfection, so that they are at $\sim 75 \%$ confluence.

2. Mix the JetPEI ${ }^{\circledR}$ reagent gently by inverting the tube. For each $15-\mathrm{cm}$ dish, dilute $50 \mu 1$ of jet PEI ${ }^{\circledR}$ in $450 \mu 1$ of plain DMEM medium (without any supplement). Prepare the total volume needed depending on the number of dishes $\left(500 \mu \mathrm{l}\right.$ of JetPEI ${ }^{\circledR}$ in $4.5 \mathrm{ml}$ of DMEM if 10 dishes are used).

3. Mix well, spin shortly to collect the whole volume at the bottom of the tube, and leave under the hood for $5 \mathrm{~min}$.

4. Dilute $25 \mu \mathrm{g}$ of plasmid DNA in $500 \mu \mathrm{l}$ of plain DMEM per one dish. Prepare the total volume needed for all dishes ( $250 \mu \mathrm{g}$ of DNA in $5 \mathrm{ml}$ of DMEM for 10 dishes).

5. Add the diluted jetPEI ${ }^{\circledR}$ into the diluted DNA and vortex vigorously for $15 \mathrm{~s}$. Leave under the hood for 15-30 min before transfection, without exceeding $30 \mathrm{~min}$.

$\triangle$ CRITICAL STEP Always add the diluted jetPEI ${ }^{\circledR}$ into diluted DNA, and not the other way around. Strictly observe vortexing time. This is essential to form transfectionefficient DNA-jetPEI ${ }^{\circledR}$ complexes.

6. During the 15 -min waiting time, replace the complete medium of the cells with the fresh, pre-heated medium.

7. Gently tap the DNA-jetPEI ${ }^{\circledR}$ mix from step 5 and add $1 \mathrm{ml}$ of it dropwise onto each dish. Mix by swirling gently and return to the incubator.

\section{Drug treatment}

1. Prepare the drug at the right dilution. For trichostatin A (TSA), an inhibitor of the tubulin deacetylase HDAC $6^{47,48}$, add $1.2 \mu 1$ of $10 \mathrm{mM}$ TSA to $12 \mathrm{ml}$ of fresh medium, per dish (final concentration of $1 \mu \mathrm{M}$ ). Prepare enough TSA depending on the number of dishes (12 $\mu 1$ of $10 \mathrm{mM}$ TSA in $120 \mathrm{ml}$ of medium if 10 dishes are used).

2. Leave the drug on the cells for the desired time, depending on the drug. For trichostatin $A$ (TSA), cells are exposed to the drug for $4 \mathrm{~h}$ in the cell culture incubator prior to cell harvest. 


\section{Box 3: Analysis of the obtained tubulin}

You can follow the enrichment of tubulin throughout the purification procedure using a Coomassie-stained SDS-PAGE gel. We also suggest quantifying obtained tubulin on an SDSPAGE gel, as in our hands, spectrometry methods do not give a good reading of the tubulin concentration. Tubulin sample can be further analysed for the presence of expected tubulin isotypes or PTMs by immunoblotting. We recommend using the custom-made "TUB" gels, which allow the separation of $\alpha$ - and $\beta$-tubulins ${ }^{49}$.

\section{Analysis sample preparation}

The volume of the sample collected from each step, but especially from the latest steps, where the volume of the sample can be very limited, depends on the extent of analysis needed. If only prep success and quantification are envisaged, $1 \mu 1$ of the final solution is sufficient. In case immunoblot analysis is necessary, it is useful to prepare up to $4 \mu 1$ of the solution, giving the possibility to run several SDS-PAGE gels. Add the same volume of $2 \mathrm{x}$ Laemmli sample buffer and boil the sample for $5 \mathrm{~min}$.

\begin{tabular}{|c|c|c|c|c|c|c|c|}
\hline \multicolumn{2}{|c|}{ Initial sample } & \multicolumn{4}{|c|}{ Sample for analysis } & \multicolumn{2}{|c|}{ Loading } \\
\hline $\begin{array}{l}\text { Sample } \\
\text { name }\end{array}$ & Volume & $\begin{array}{l}\text { Fraction } \\
\text { collected }\end{array}$ & $\begin{array}{l}\text { Volume } \\
\text { collected }\end{array}$ & $\begin{array}{l}\begin{array}{l}\text { Volume } \\
\text { of } 2 \mathrm{x}\end{array} \\
\text { Laemmli } \\
\text { sample } \\
\text { buffer } \\
\text { added }\end{array}$ & $\begin{array}{l}\text { Further } \\
\text { dilution }\end{array}$ & $\begin{array}{l}\text { Volume of the } \\
\text { initial sample } \\
\text { to be loaded }\end{array}$ & $\begin{array}{l}\text { Volume of } \\
\text { analysis sample } \\
\text { to load } 1 / 2,400^{\text {th }} \\
\text { of the initial } \\
\text { sample }\end{array}$ \\
\hline $\mathrm{L}$ & $20 \mathrm{ml}$ & $1 / 100^{\text {th }}$ & $200 \mu 1$ & $200 \mu 1$ & - & $8.33 \mu 1$ & $16.67 \mu 1$ \\
\hline SN1, P1 & $12 \mathrm{ml}$ & $1 / 100^{\text {th }}$ & $120 \mu 1$ & $120 \mu 1$ & - & $5 \mu 1$ & $10 \mu 1$ \\
\hline $\begin{array}{l}\text { SN2, P2, } \\
\text { SN3, P3, } \\
\text { SN4 }\end{array}$ & $200 \mu 1$ & $\begin{array}{l}1 / 200^{\text {th }} \\
\text { or } 1 / 50^{\text {th }}\end{array}$ & 1 or $4 \mu 1$ & 9 or $36 \mu 1$ & $10 x$ & $0.083 \mu 1$ & $8.3 \mu 1$ \\
\hline $\begin{array}{l}\mathrm{P} 4, \mathrm{SN} 5, \\
\mathrm{P} 5, \mathrm{SN} 6, \\
\mathrm{P} 6, \mathrm{SN} 7, \\
\mathrm{P} 7\end{array}$ & $120 \mu 1$ & $\begin{array}{l}1 / 120^{\text {th }}- \\
1 / 30^{\text {th }}\end{array}$ & 1 or $4 \mu 1$ & 9 or $36 \mu 1$ & $10 \mathrm{x}$ & $0.05 \mu 1$ & $5 \mu 1$ \\
\hline
\end{tabular}

\section{Tubulin purification quality test}

To verify the success and purity of the tubulin purified using this protocol, we use

Coomassie-stained SDS-PAGE gels allowing to separate $\alpha$ - and $\beta$-tubulins and which have 
been described previousely ${ }^{49}$. We suggest loading an equal fraction of each sample from the purification steps to assess the enrichment of tubulin (Fig. 4a).

\section{Quantification of the tubulin}

We quantify the tubulin using standardised BSA samples. Two dilutions of the tubulin sample are loaded on an SDS-PAGE gel next to a range of different, known quantities of

BSA protein $(0.5 \mu \mathrm{g}-1 \mu \mathrm{g}-2 \mu \mathrm{g}-4 \mu \mathrm{g})$. After staining the gel with Coomassie brilliant blue and scanning it, you can deduce the concentrations of $\alpha$ - and $\beta$-tubulins in your sample using the linear regression of the BSA-band intensities.

$\triangle$ CRITICAL STEP Make sure the scanner is set to a linear range, and do not manipulate the contrast setting to allow a correct determination of relative intensities of the analysed bands.

\section{Analysis of obtained tubulin by immunoblot (Fig. 4b-d)}

In order to confirm the presence of desired tubulin PTMs, we recommend immunoblot analysis. Based on the quantification of the purified tubulin, load between $0.1-0.5 \mu \mathrm{g}$ of tubulin on a "TUB" SDS-PAGE gel (allowing to separate $\alpha$ - and $\beta$-tubulins ${ }^{49}$ ). As the antibodies towards tubulin PTMs are very specific and give strong signals already at low tubulin concentrations, it is crucial to load a small amount of the tubulin sample. We also avoid incubating the membranes with the antibodies for more than $2 \mathrm{~h}$ at room temperature. Always check the equal loading of your samples by performing an immunoblot with a PTM-independent anti- $\alpha$-tubulin antibody (12G10) and include a positive control, for example brain tubulin. 


\section{TIMING}

Step 1, preparing tubulin source: 5-13 days

Step 1A, cells grown in spinners: 10-13 days

Steps 1A(i-iii), cell amplification (on plates): 3-6 days

Steps 1A(iv-xi), inoculation of spinners: $\sim 2 \mathrm{~h}$

Step 1A(xii) cell growth in spinners: 7 days

Steps 1A(xiv-xx), harvesting cells: $\sim 90 \mathrm{~min}$

Step 1B, adherent cells : 5-6 days

Steps 1B(i-ii), cell amplification: 5-6 days

Box 2, treatment of cells: 1-4 h

Steps 1B(iii-x), harvesting cells: $\sim 1 \mathrm{~h}$

Steps 1C(i-ii), mouse brain: 15 min (not considering the time necessary to breed the donor mouse)

Step 2, lysis: $30 \mathrm{~min}$

steps 2A, HEK-293 cells: $30 \mathrm{~min}$

steps 2B, Hela S3 cells: $30 \mathrm{~min}$

steps $2 \mathrm{C}$, mouse brain: $30 \mathrm{~min}$

Steps 3-6, lysate clarification: $\sim 30 \mathrm{~min}$

Steps 7-11, first polymerisation and warm spin: $\sim 1 \mathrm{~h}$

Steps 12-17, first de-polymerisation and cold spin: $\sim 1 \mathrm{~h}$

Step 18, (optional) enzymatic treatment: $10 \mathrm{~min}-1 \mathrm{~h}$

Steps 19-23, second polymerisation and warm spin: $\sim 1 \mathrm{~h}$

Steps 24-30, second de-polymerisation and cold spin: $\sim 50 \mathrm{~min}$

Steps 31-35, (optional) third polymerisation and warm spin: $\sim 1 \mathrm{~h}$

Steps 36-40, (optional)third de-polymerisation and cold spin: $\sim 50 \mathrm{~min}$

Step 41, Box 3, quantification of obtained tubulin: $10 \mathrm{~min}-3 \mathrm{~h}$

Step 42, aliquoting and snap freezing: 10-30 min 


\section{TROUBLESHOOTING}

\begin{tabular}{|c|c|c|c|}
\hline step & problem & \begin{tabular}{|l|} 
Possible reason \\
\end{tabular} & Possible solution \\
\hline \multirow{4}{*}{$1 \mathrm{~A}(\mathrm{xii})$} & $\begin{array}{l}\text { Large cell } \\
\text { aggregates } \\
\text { (Fig. 2b,c) }\end{array}$ & $\begin{array}{l}\text { Too low rotation speed in } \\
\text { spinner cultures }\end{array}$ & Increase the speed of rod rotation \\
\hline & $\begin{array}{l}\text { Lack of cell } \\
\text { growth }\end{array}$ & Closed lateral spinner flask caps & $\begin{array}{l}\text { Open the lateral caps slightly (half } \\
\text { a turn) to allow air exchange }\end{array}$ \\
\hline & \multirow{2}{*}{$\begin{array}{l}\text { Bacterial or fungal } \\
\text { contamination }\end{array}$} & $\begin{array}{l}\text { Contamination carried inside the } \\
\text { cell culture hood via media or } \\
\text { spinner bottles }\end{array}$ & $\begin{array}{l}\text { Clean all bottles with } 70 \% \text { ethanol } \\
\text { before transferring them under the } \\
\text { hood }\end{array}$ \\
\hline & & $\begin{array}{l}\text { Manipulation (transfer between } \\
\text { the bottle and the spinner flasks) } \\
\text { of large quantities of media }\end{array}$ & $\begin{array}{l}\text { Manipulate media with more care; } \\
\text { avoid spilling the medium }\end{array}$ \\
\hline \multirow[b]{2}{*}{ 1B(vi) } & \multirow{2}{*}{$\begin{array}{l}\text { Lysis of cells } \\
\text { during detachment } \\
\text { from plastic dishes }\end{array}$} & Too brutal treatment of cells & $\begin{array}{l}\text { Collect the cells by gently } \\
\text { lifting/shovelling them to one side } \\
\text { of the dish }\end{array}$ \\
\hline & & Too slow detachment of cells & $\begin{array}{l}\text { Prepare all the necessary material } \\
\text { in forehand and ask two } \\
\text { colleagues for help with this part } \\
\text { of the procedure }\end{array}$ \\
\hline \multirow{6}{*}{10} & $\begin{array}{l}\text { Large pellet after } \\
1^{\text {st }} \text { polymerisation, } \\
\text { but devoid of } \\
\text { tubulin }\end{array}$ & $\begin{array}{l}\text { Insufficient clearing of the lysate } \\
\text { in step } 4 \mathrm{~B} \text { (iii) }\end{array}$ & $\begin{array}{l}\text { Collect only clear supernatant in } \\
\text { step } 4 \text {. Further clarify the } \\
\text { supernatant by centrifugation in } \\
\text { step 4B(iii). }\end{array}$ \\
\hline & \multirow{5}{*}{$\begin{array}{l}\text { No microtubule } \\
\text { pellet after } 1^{\text {st }} \\
\text { polymerisation }\end{array}$} & $\begin{array}{l}\text { Insufficient tubulin concentration } \\
\text { due to incomplete lysis in step } 2\end{array}$ & $\begin{array}{l}\text { Verify the lysis of the cells and } \\
\text { extend incubation time at } 4^{\circ} \mathrm{C} \\
\text { prior to clarification in step } 2\end{array}$ \\
\hline & & $\begin{array}{l}\text { Incorrect cell treatment prior to } \\
\text { lysis in step } 1 \mathrm{~B}(\mathrm{vi})\end{array}$ & $\begin{array}{l}\text { Speed up cell collection procedure } \\
\text { and avoid breaking the cells } \\
\text { before the lysis step } 1 \mathrm{~B}(\mathrm{vi})\end{array}$ \\
\hline & & $\begin{array}{l}\text { Insufficient tubulin concentration } \\
\text { in the cell extract }\end{array}$ & $\begin{array}{l}\text { Lysis buffer volume should not } \\
\text { exceed the volume of the cell } \\
\text { pellet in steps } 1 \mathrm{~A}(\mathrm{xx}) ; 1 \mathrm{~B}(\mathrm{x})\end{array}$ \\
\hline & & Hydrolysed GTP & Use a fresh aliquot of GTP \\
\hline & & $\begin{array}{l}\text { Reaction carried out at wrong } \\
\text { temperature }\end{array}$ & $\begin{array}{l}\text { Check the temperature of the } \\
\text { water-bath with a thermometer }\end{array}$ \\
\hline \multirow[b]{2}{*}{22} & \multirow{2}{*}{$\begin{array}{l}\text { No microtubule } \\
\text { pellet after } 2^{\text {nd }} \\
\text { polymerisation }\end{array}$} & $\begin{array}{l}\text { Insufficient tubulin concentration } \\
\text { after } 1^{\text {st }} \text { depolymerisation }\end{array}$ & $\begin{array}{l}\text { Depolymerise tubulin in lower } \\
\text { volume in step } 12\end{array}$ \\
\hline & & $\begin{array}{l}\text { Incomplete tubulin de- } \\
\text { polymerisation in steps } 12-14\end{array}$ & $\begin{array}{l}\text { Repeat the depolymerisation } \\
\text { procedure in steps } 12-15 \text { on the } \\
\text { pellet P3 from step } 15\end{array}$ \\
\hline \multirow{2}{*}{$\begin{array}{l}\text { Box } 3 \\
\text { Step } 4\end{array}$} & \multirow{2}{*}{$\begin{array}{l}\text { Lack of expected } \\
\text { modification on } \\
\text { purified tubulin }\end{array}$} & $\begin{array}{l}\text { Failed transfection of cells or } \\
\text { drug treatment }\end{array}$ & $\begin{array}{l}\text { Use freshly thawed cells, check } \\
\text { the quality of plasmid DNA, adapt } \\
\text { drug treatment protocol }\end{array}$ \\
\hline & & $\begin{array}{l}\text { Overloading of the SDS-PAGE } \\
\text { gel with the sample }\end{array}$ & $\begin{array}{l}\text { Dilute the sample to load } 0.2- \\
0.5 \mu \mathrm{g} \text { of tubulin }\end{array}$ \\
\hline
\end{tabular}




\section{ANTICIPATED RESULTS}

The key application of the here-described tubulin purification protocol are advanced in vitro reconstitutions of microtubule assemblies using tubulin purified from cell lines or mouse brains with controlled tubulin PTMs. The rationale of our approach was to adapt the method considered the gold standard for tubulin purification; the repeated polymerisation and depolymerisation of brain tubulin, to purify tubulin from other sources. Using our protocol, we obtained reproducible high-quality, highly pure tubulin (Fig. 4a). Due to the relatively small sample sizes (as compared to the previously used brain-tubulin purification), our protocol showed some variations in yield, but never in quality.

If initially posttranslationally modified, the tubulin purified by our protocol maintains all of the commonly studied PTMs (Fig. 4b-d), and can therefore be used to compare differentially modified microtubules side-by-side ${ }^{20,21}$. However, it should be kept in mind, and eventually tested, that the repeated polymerisation and depolymerisation cycles could bias the composition of the final tubulin. For quantitative analyses of the tubulin composition, the method by Widlund et al. ${ }^{28}$ should be used.

The quantities of tubulin obtained by our protocol are sufficient for a wide range of applications. Using a set of four spinner bottles that are maintained continuously, which is possible with Hela S3 cells that can be constantly diluted without adherent pre-cultures, a laboratory can produce $\sim 2 \mathrm{mg}$ of tubulin per week with a work input of about one day for the tubulin purification. This work load could be even further reduced by collecting cells at $-80^{\circ} \mathrm{C}$ and for a larger-scale tubulin purification. For most TRIF-based assays, only $\mu \mathrm{g}$-amounts of tubulin are needed, thus, the PTM-free Hela S3 tubulin produced by this protocol could fully replace brain tubulin for an entire research team. Even classic microtubule co-sedimentation assays, though more tubulin-consuming, require $\sim 100 \mu \mathrm{g}$ of pure tubulin for one dilution series $^{50,51}$, and can thus easily be performed with tubulin purified with our protocol. The yield of tubulin from single mouse brains is also sufficient to perform virtually all known in vitro approaches, given that the mouse strain is easy to breed and sufficient numbers of brains can be obtained. The great advantage of purifying tubulin from a single mouse brain is that biological replicates can be introduced in the in-vitro approach; as multiple tubulin samples from individual mouse brains can be used side-by-side.

The most work-intense approach is the purification of tubulin from adherently growing cells. The great advantage of this approach is that it allows to generate virtually any type of posttranslationally modified tubulin, given the availability of a wide range of modifying enzymes ${ }^{52-59}$. We recommend to use this method after only an assay has duly be established 
using brain tubulin or non-modified tubulin from cells grown in spinner cultures, which are easier to produce.

Our protocol thus could allow research teams that perform in vitro reconstitution assays to fully replace brain tubulin by Hela S3 tubulin, a tubulin free of PTMs and exotic tubulin isotypes, on a daily basis. By expanding the protocol to the purification of tubulin modified with a variety of PTMs, their role can now be directly studied in vitro, which was so far virtually impossible. The proof of principle has been provided by the direct comparison of fully tyrosinated and fully detyrosinated Hela S3 tubulin in single-molecule motility assays and force measurements for the kinetochore kinesin $\mathrm{CENP}^{20}{ }^{20}$, binding assays of neuronal kinesin motors ${ }^{22}$, or in transport assays with purified neuronal transport vesicles ${ }^{21}$. These examples demonstrate that PTM-free tubulin obtained by our protocol could be a valid replacement of the so-far used brain tubulin in all currently used in vitro reconstitution assays. 


\section{AKNOWLEDGEMENTS}

We thank all members of the Janke lab for help during the establishment of the protocol. We would like to thank the animal facility of the Institut Curie for help with mouse breeding and care.

This work has received support under the program "Investissements d'Avenir" launched by the French Government and implemented by ANR with the references ANR-10-LBX-0038, ANR-10-IDEX-0001-02 PSL. The work of CJ was supported by the Institut Curie, the French National Research Agency (ANR) award ANR-12-BSV2-0007, the Institut National du Cancer (INCA) grants 2013-1-PL BIO-02-ICR-1 and 2014-PL BIO-11-ICR-1, the Fondation pour la Recherche Medicale (FRM) grant DEQ20170336756, and the CEFIPRA research project 5703-1. MMM is supported by the EMBO short-term fellowship ASTF 148-2015 and by the Fondation Vaincre Alzheimer grant FR-16055p. JS was supported by the FRM fellowship SPF20120523942, and the EMBO ALTF 638-2010 and EMBO ASTF 445-2012. SB was supported by the FRM grant FDT201805005465. JAS was supported by the European Union's Horizon 2020 research and innovation programme under the Marie SkłodowskaCurie grant agreement No 675737. The antibody 12G10, developed by J. Frankel and M. Nelson, was obtained from the Developmental Studies Hybridoma Bank developed under the auspices of the NICHD and maintained by the University of Iowa.

\section{AUTHOR CONTRIBUTION}

J.S. and M.M.M. established, with the help of G.L. and A.G., the spinner cultures for various cell lines and adapted the tubulin purification protocol to spinner-grown cells. S.B. and M.M.M. established the tubulin prep from adherent cells and S.B. and M.M.M. and J.A.S. contributed to improving the protocol of the tubulin prep from large cell quantities. M.M.M. established the tubulin prep protocol from single mouse brains. M.M.M. and C.J. supervised the development of this method and wrote the manuscript. All the authors contributed to corrections of the text and figures.

\section{COMPETING FINANCIAL INTEREST STATEMENT}

The authors declare that they have no competing financial interests. 


\section{Figure 1: Flow scheme of the tubulin purification protocol.}

Different steps of the tubulin purification are schematically depicted. After the lysis and lysate clarification (Steps 2-4), the first polymerisation is carried out in low-molarity conditions (low-molarity pol; polymerisation 1, Steps 7-10). Microtubules are then pelleted, depolymerised, and soluble tubulin is clarified (depolymerisation 1, Steps 12-15). Soluble tubulin is then subjected to a high-molarity polymerisation, excluding the MAPs (polymerisation and depolymerisation 2, Steps 19-28). After polymerisation 2 it is possible to purify microtubule-associated proteins (MAPs). Tubulin can be further subjected to a third, low-molarity polymerisation followed by depolymerisation (polymerisation and depolymerisation 3, Steps 31-39), in order to completely remove the high-molarity buffer from polymerisation 2 .

The temperature of the step is indicated by the background colour. The nature of the discarded fraction is indicated as well as the possible pause points (optional freezing steps) and additional treatment. Approximative timing of each step is also given.

\section{Figure 2: Growing Hela S3 and HEK-293 cells in spinner cultures for tubulin purification.}

a. Overview of the spinner culture (step 1A): Cells are first grown on 15-cm plates to $80-90 \%$ confluence. They are then detached, thoroughly dissociated and inoculated in spinner bottles. The bottles are then incubated for 7 days in a cell culture incubator equipped with a rotating table. Optionally, cells can be treated one or two days before being harvested and proceeded for the tubulin purification (see Fig. 3).

b. Close-up view of the spinners with medium only, just after inoculation and after 7 days of culture of Hela S3 and HEK-293 cells (Step 1A(xii)). Note the homogeneous aspect of Hela S3 culture after 7 days, in contrast to the aggregates formed by HEK-293 cells. These cell aggregates are visible to naked eye.

c. Representative images of Hela S3 and HEK-293 cells grown on plastic dishes, after spinner inoculation and after 7 days in the spinners. Note that HEK-293 form cell aggregates up to several hundred $\mu \mathrm{m}$ in diameter. Scale bar: $50 \mu \mathrm{m}$.

Figure 3: Tubulin purification from cells cultured in spinner bottles. 
a. Collecting the cells (Steps 1A(xiv-xx)): Cells grown for 7 days in spinners are transferred to 1-1 bottles and pelleted. Cells are re-suspended in PBS and transferred to a 50-ml conical tube and pelleted again. The pellet volume is recorded and cells are re-suspended in the same volume of lysis buffer.

b. The set-up used to lyse the cells: while Hela S3 cells are broken using a French press, HEK-293 cells are lysed by repeated passages through a p1000 tip tightly fitted on a 5-ml pipette. Both HEK-239 and Hela S3 cell lysates are then repeatedly passed through a p200 tip fitted on a p1000 tip on a p1000 pipette (steps 2A(i) and 2B(ii)).

c. Representative images of Hela S3 and HEK-293 cells before and after lysis (steps 2A and 2B). Note the presence of cell debris (purple crosses) in the lysates. Scale bar $50 \mu \mathrm{m}$.

d. Images of the purification process (steps 3-28): After ultracentrifugation, cleared cell lysates contains a white floating layer $(\rightarrow)$. If this material is transferred together with the supernatant, making it turbid (*), it can be efficiently clarified in a step of low-speed centrifugation. The first-polymerisation microtubule pellet has a white and uneven appearance (\#). Following the first depolymerisation and cold centrifugation, a pellet is well visible (\$). The second polymerisation gives a clear and transparent pellet $(€)$. The second depolymerisation produces a very small, hardly visible microtubule pellet $(>>)$.

\section{Figure 4: Analyses of purified tubulin obtained from cell lines and mice brains.}

a. Coomassie-stained acrylamide gel with samples of different steps throughout the tubulin purification procedure. Note the enrichment of $\alpha$ - and $\beta$-tubulin throughout the procedure until its pure fraction (P4), and the tubulin-free fraction containing only MAPs (SN4). Tubulin from P4 can be further submitted to depolymerisation - polymerisation cycles (not shown).

b. Generation of totally tyrosinated and totally detyrosinated Hela S3 tubulin. Immunoblot analysis of purified pig brain, untreated Hela S3 tubulin, and Hela S3 tubulin treated with carboxypeptidase A (+CPA). While brain tubulin is a mixture of tyrosinated and detyrosinated tubulin, untreated Hela S3 tubulin is entirely tyrosinated. This tyrosinated tubulin is fully converted to detyrosinated tubulin by using CPA.

c. Different patterns of tubulin polyglutamylation following overexpression of TTLL5 or TTLL7. Immunoblot analysis of tubulin purified from HEK-293 cells overexpressing 
polyglutamylases TTLL5 or TTLL7. Note that while HEK-293 cells have very low levels of tubulin polyglutamylation, TTLL5 overexpression leads to polyglutamylation of both $\alpha$ - and $\beta$-tubulin, while TTLL7 modifies only $\beta$-tubulin.

d. Polyglutamylation levels of tubulin purified from brains of wild-type, atat1 ${ }^{-/-}$and $t t l l 1^{-/-}$ mice. Knockout of aTAT1, the tubulin acetyltransferase ${ }^{58,59}$, leads to the loss of acetylation of lysine K40 of $\alpha$-tubulin. TTLL1, main brain glutamylase ${ }^{52}$, leads to a reduction of tubulin polyglutamylation.

Note that a special acrylamide gels have been used, which allow to separate $\alpha$ - and $\beta$-tubulin bands that usually co-migrate slightly above $50 \mathrm{kDa}^{49}$. In $\mathbf{b}, \mathbf{c}$ and $\mathbf{d}$ equal levels of total tubulin were verified with $12 \mathrm{G} 10$, an anti- $\alpha$-tubulin antibody.

Experimental procedures involving animals were specifically approved by the ethics committee of the Institut Curie CEEA-IC \#118 (authorization no. 04395.03 given by National Authority) in compliance with the international guidelines. 


\section{REFERENCES}

1 Borisy, G. G. \& Taylor, E. W. The mechanism of action of colchicine. Binding of colchincine-3H to cellular protein. J Cell Biol 34, 525-533 (1967).

2 Weisenberg, R. C. Microtubule formation in vitro in solutions containing low calcium concentrations. Science 177, 1104-1105 (1972).

3 Borisy, G. G. \& Olmsted, J. B. Nucleated assembly of microtubules in porcine brain extracts. Science 177, 1196-1197 (1972).

4 Kirschner, M. W. \& Williams, R. C. The mechanism of microtubule assembly in vitro. J Supramol Struct 2, 412-428 (1974).

5 Margolis, R. L. \& Wilson, L. Addition of colchicine-tubulin complex to microtubule ends: the mechanism of substoichiometric colchicine poisoning. Proc Natl Acad Sci U $S$ A 74, 3466-3470 (1977).

6 Murphy, D. B. \& Borisy, G. G. Association of high-molecular-weight proteins with microtubules and their role in microtubule assembly in vitro. Proc Natl Acad Sci U S A 72, 2696-2700 (1975).

7 Margolis, R. L. \& Wilson, L. Opposite end assembly and disassembly of microtubules at steady state in vitro. Cell 13, 1-8 (1978).

8 Mitchison, T. \& Kirschner, M. Dynamic instability of microtubule growth. Nature 312, 237-242 (1984).

9 Axelrod, D. Cell-substrate contacts illuminated by total internal reflection fluorescence. J Cell Biol 89, 141-145 (1981).

10 Dogterom, M. \& Surrey, T. Microtubule organization in vitro. Curr Opin Cell Biol 25, 23-29 (2013).

11 Nedelec, F. J., Surrey, T., Maggs, A. C. \& Leibler, S. Self-organization of microtubules and motors. Nature 389, 305-308 (1997).

12 Bieling, P., Telley, I. A. \& Surrey, T. A minimal midzone protein module controls formation and length of antiparallel microtubule overlaps. Cell 142, 420-432 (2010).

13 Roostalu, J. et al. Directional switching of the kinesin Cin8 through motor coupling. Science 332, 94-99 (2011).

14 Hendricks, A. G., Goldman, Y. E. \& Holzbaur, E. L. F. Reconstituting the motility of isolated intracellular cargoes. Methods Enzymol 540, 249-262 (2014).

15 Schaedel, L. et al. Microtubules self-repair in response to mechanical stress. Nat Mater 14, 1156-1163 (2015).

16 Vallee, R. B. Reversible assembly purification of microtubules without assemblypromoting agents and further purification of tubulin, microtubule-associated proteins, and MAP fragments. Methods Enzymol 134, 89-104 (1986).

17 Castoldi, M. \& Popov, A. V. Purification of brain tubulin through two cycles of polymerization-depolymerization in a high-molarity buffer. Protein Expr Purif 32, 8388 (2003).

18 Wloga, D., Joachimiak, E., Louka, P. \& Gaertig, J. Posttranslational Modifications of Tubulin and Cilia. Cold Spring Harb Perspect Biol 9 (2017).

19 Janke, C. The tubulin code: Molecular components, readout mechanisms, and functions. J Cell Biol 206, 461-472 (2014).

20 Barisic, M. et al. Microtubule detyrosination guides chromosomes during mitosis. Science 348, 799-803 (2015).

21 Nirschl, J. J., Magiera, M. M., Lazarus, J. E., Janke, C. \& Holzbaur, E. L. F. alphaTubulin Tyrosination and CLIP-170 Phosphorylation Regulate the Initiation of Dynein-Driven Transport in Neurons. Cell Rep, celrep 2509 (2016). 
22 Guedes-Dias, P. et al. Kinesin-3 Responds to Local Microtubule Dynamics to Target Synaptic Cargo Delivery to the Presynapse. Curr Biol 29, 268-282 e268 (2019).

23 Bulinski, J. C. \& Borisy, G. G. Self-assembly of microtubules in extracts of cultured HeLa cells and the identification of HeLa microtubule-associated proteins. Proc Natl Acad Sci U S A 76, 293-297 (1979).

24 Farrell, K. W. Isolation of tubulin from nonneural sources. Methods Enzymol 85 Pt B, 385-393 (1982).

25 Banerjee, A., Roach, M. C., Trcka, P. \& Ludueña, R. F. Preparation of a monoclonal antibody specific for the class IV isotype of beta-tubulin. Purification and assembly of alpha beta II, alpha beta III, and alpha beta IV tubulin dimers from bovine brain. $J$ Biol Chem 267, 5625-5630 (1992).

26 Newton, C. N. et al. Intrinsically slow dynamic instability of HeLa cell microtubules in vitro. J Biol Chem 277, 42456-42462 (2002).

27 Lacroix, B. \& Janke, C. Generation of differentially polyglutamylated microtubules. Methods Mol Biol 777, 57-69 (2011).

28 Widlund, P. O. et al. One-step purification of assembly-competent tubulin from diverse eukaryotic sources. Mol Biol Cell 23, 4393-4401 (2012).

29 Howes, S. C. et al. Structural differences between yeast and mammalian microtubules revealed by cryo-EM. J Cell Biol 216, 2669-2677 (2017).

30 Pamula, M. C., Ti, S.-C. \& Kapoor, T. M. The structured core of human beta tubulin confers isotype-specific polymerization properties. J Cell Biol 213, 425-433 (2016).

31 Vemu, A., Atherton, J., Spector, J. O., Moores, C. A. \& Roll-Mecak, A. Tubulin isoform composition tunes microtubule dynamics. Mol Biol Cell 28, 3564-3572 (2017).

32 von Loeffelholz, O. et al. Nucleotide- and Mal3-dependent changes in fission yeast microtubules suggest a structural plasticity view of dynamics. Nat Commun 8, 2110 (2017).

33 Chaaban, S. et al. The Structure and Dynamics of C. elegans Tubulin Reveals the Mechanistic Basis of Microtubule Growth. Dev Cell 47, 191-204 e198 (2018).

34 Alper, J. D., Decker, F., Agana, B. \& Howard, J. The motility of axonemal dynein is regulated by the tubulin code. Biophys $J$ 107, 2872-2880 (2014).

35 Minoura, I. et al. Overexpression, purification, and functional analysis of recombinant human tubulin dimer. FEBS Lett 587, 3450-3455 (2013).

36 Vemu, A. et al. Structure and Dynamics of Single-isoform Recombinant Neuronal Human Tubulin. J Biol Chem 291, 12907-12915 (2016).

37 Ti, S.-C., Alushin, G. M. \& Kapoor, T. M. Human beta-Tubulin Isotypes Can Regulate Microtubule Protofilament Number and Stability. Dev Cell 47, 175-190 e175 (2018).

38 Uchimura, S. et al. A flipped ion pair at the dynein-microtubule interface is critical for dynein motility and ATPase activation. J Cell Biol 208, 211-222 (2015).

39 Denoulet, P., Eddé, B. \& Gros, F. Differential expression of several neurospecific beta-tubulin mRNAs in the mouse brain during development. Gene 50, 289-297 (1986).

40 Song, Y. et al. Transglutaminase and polyamination of tubulin: posttranslational modification for stabilizing axonal microtubules. Neuron 78, 109-123 (2013).

41 Belvindrah, R. et al. Mutation of the alpha-tubulin Tubala leads to straighter microtubules and perturbs neuronal migration. J Cell Biol 216, 2443-2461 (2017).

42 Breuss, M. et al. Mutations in the murine homologue of TUBB5 cause microcephaly by perturbing cell cycle progression and inducing p53 associated apoptosis.

Development (2016). 
43 Latremoliere, A. et al. Neuronal-Specific TUBB3 Is Not Required for Normal Neuronal Function but Is Essential for Timely Axon Regeneration. Cell Rep 24, 1865 1879 e 1869 (2018).

44 Magiera, M. M. et al. Excessive tubulin polyglutamylation causes neurodegeneration and perturbs neuronal transport. EMBO J 37, e100440 (2018).

45 Morley, S. J. et al. Acetylated tubulin is essential for touch sensation in mice. Elife 5 (2016).

46 Hiller, G. \& Weber, K. Radioimmunoassay for tubulin: a quantitative comparison of the tubulin content of different established tissue culture cells and tissues. Cell 14, 795-804 (1978).

47 Hubbert, C. et al. HDAC6 is a microtubule-associated deacetylase. Nature 417, 455458 (2002).

48 Matsuyama, A. et al. In vivo destabilization of dynamic microtubules by HDAC6mediated deacetylation. Embo J 21, 6820-6831 (2002).

49 Magiera, M. M. \& Janke, C. in Methods Cell Biol Vol. 115 Microtubules, in vitro (eds John J. Correia \& Leslie Wilson) 247-267 (Academic Press, 2013).

50 Maurer, S. P., Bieling, P., Cope, J., Hoenger, A. \& Surrey, T. GTP \{gamma $\}$ microtubules mimic the growing microtubule end structure recognized by end-binding proteins (EBs). Proc Natl Acad Sci U S A 108, 3988-3993 (2011).

51 Sandblad, L. et al. The Schizosaccharomyces pombe EB1 homolog Mal3p binds and stabilizes the microtubule lattice seam. Cell 127, 1415-1424 (2006).

52 Janke, C. et al. Tubulin polyglutamylase enzymes are members of the TTL domain protein family. Science 308, 1758-1762 (2005).

53 van Dijk, J. et al. A targeted multienzyme mechanism for selective microtubule polyglutamylation. Mol Cell 26, 437-448 (2007).

54 Rogowski, K. et al. Evolutionary divergence of enzymatic mechanisms for posttranslational polyglycylation. Cell 137, 1076-1087 (2009).

55 Rogowski, K. et al. A family of protein-deglutamylating enzymes associated with neurodegeneration. Cell 143, 564-578 (2010).

56 Aillaud, C. et al. Vasohibins/SVBP are tubulin carboxypeptidases (TCPs) that regulate neuron differentiation. Science 358, 1448-1453 (2017).

57 Nieuwenhuis, J. et al. Vasohibins encode tubulin detyrosinating activity. Science 358, 1453-1456 (2017).

58 Akella, J. S. et al. MEC-17 is an alpha-tubulin acetyltransferase. Nature 467, 218-222 (2010).

59 Shida, T., Cueva, J. G., Xu, Z., Goodman, M. B. \& Nachury, M. V. The major alphatubulin K40 acetyltransferase alphaTAT1 promotes rapid ciliogenesis and efficient mechanosensation. Proc Natl Acad Sci U S A 107, 21517-21522 (2010). 
steps 2-4: lysis and cold spin (1h)

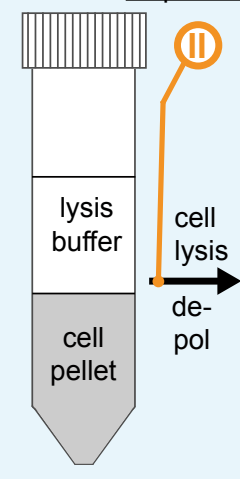

steps 24-28:

de-poly-

meri-

sation 2

and cold

spin

(50 $\mathrm{min})$

MAPs

s
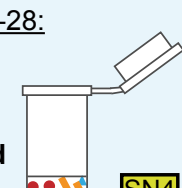

\section{steps 19-22: polymerisation 2} and warm spin (1 h)
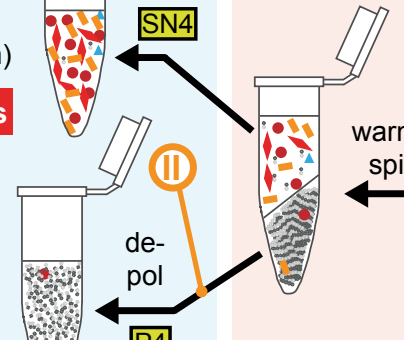

P4

steps 7-10:

polymerisation 1 and warm spin (1h)
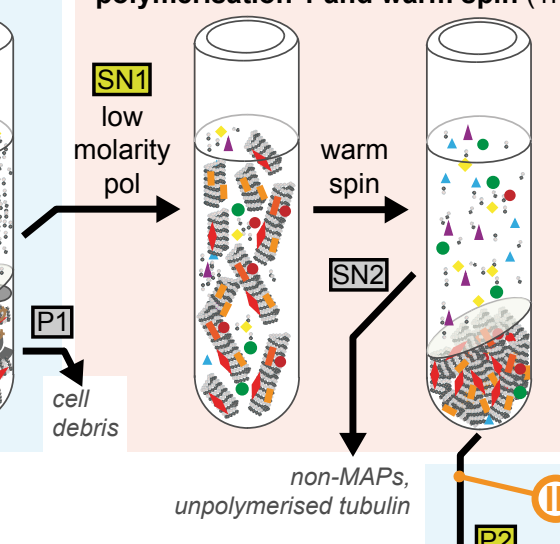

(11)

$$
\text { (1) }
$$


a

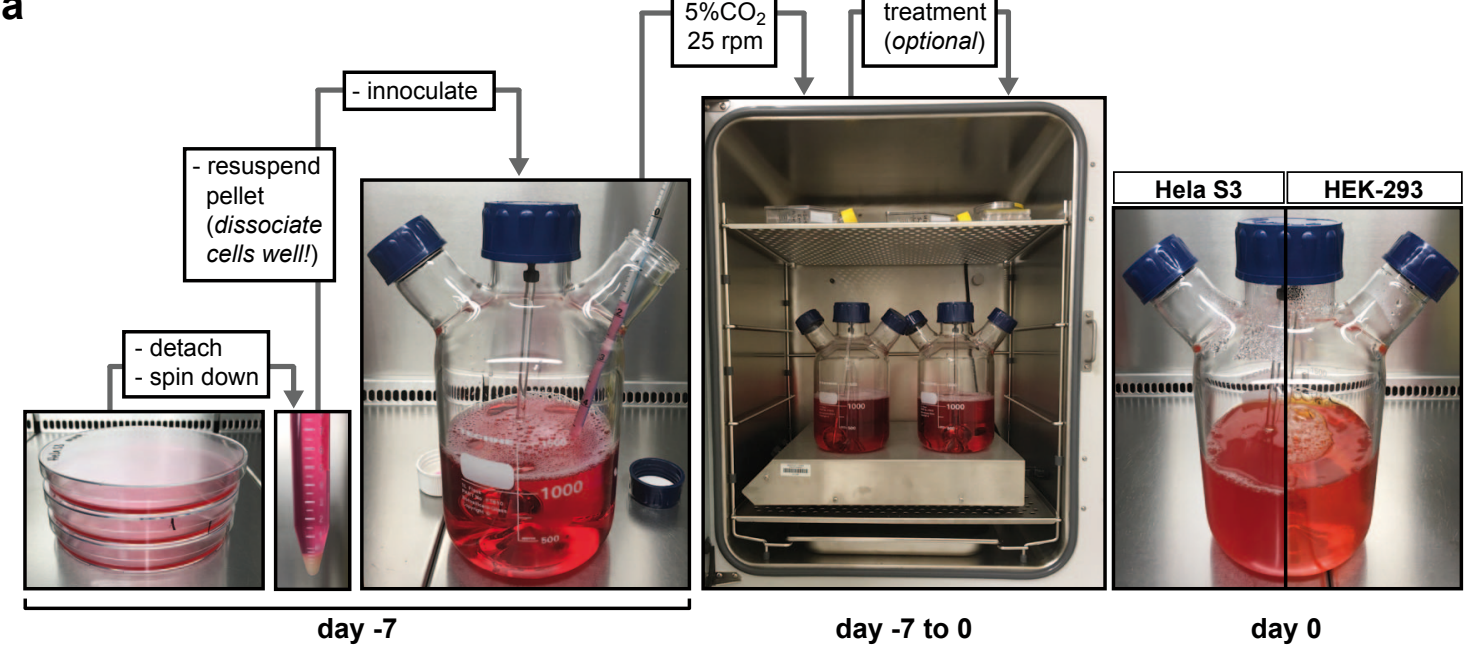

b
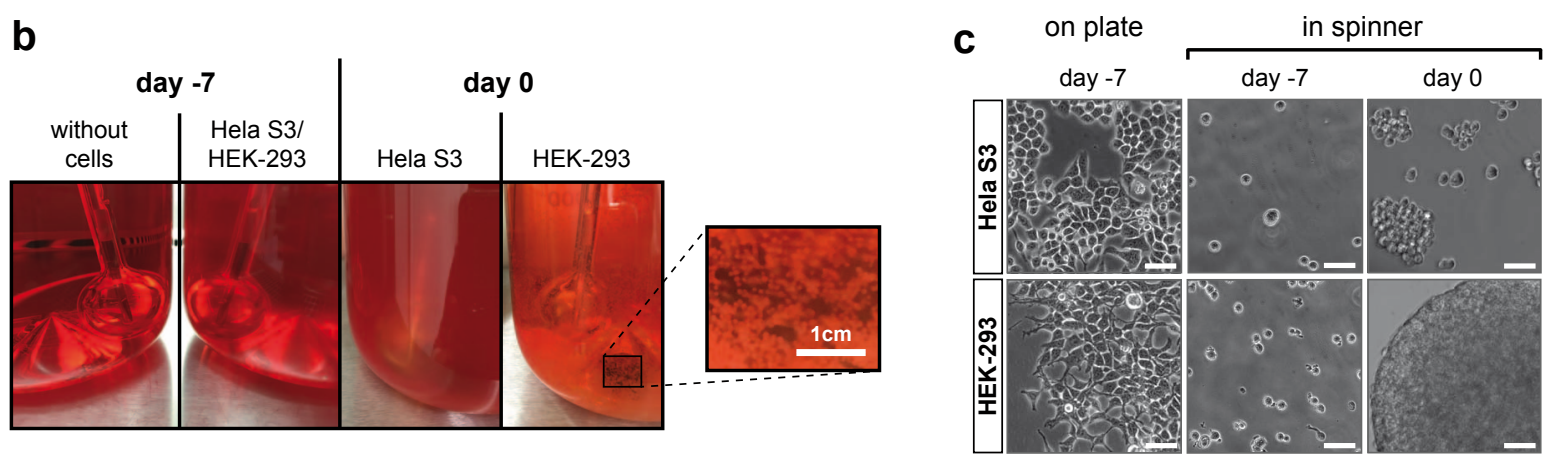
a

1-L spinner culture

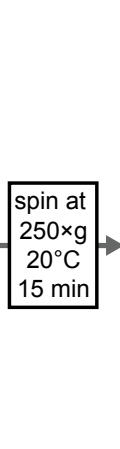

pellet of $1-L$ culture

cells in $50 \mathrm{ml}$ PBS
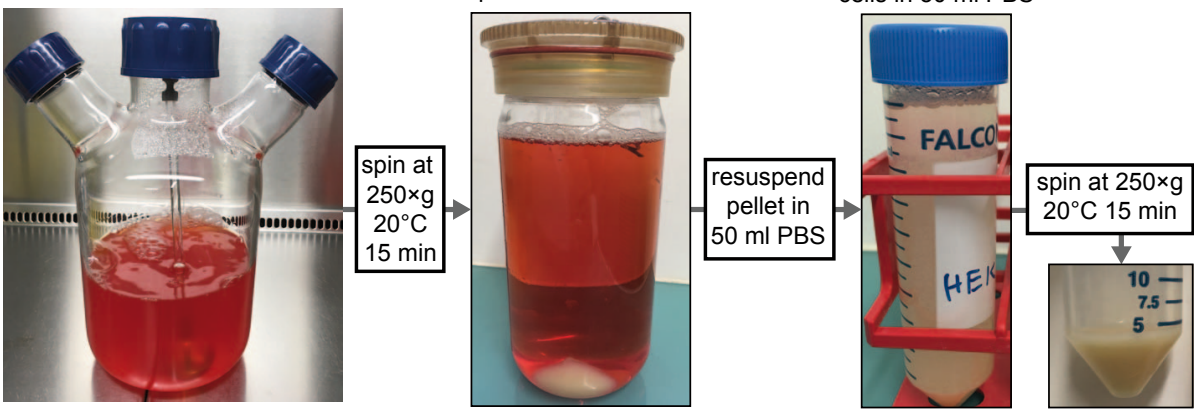

b

C

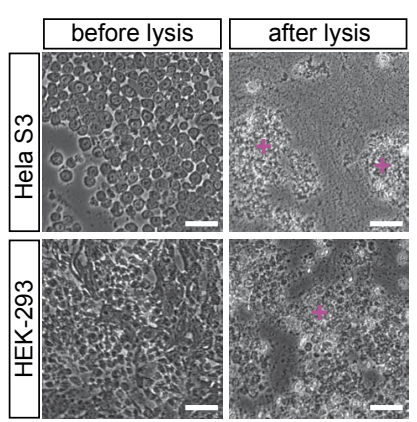

d

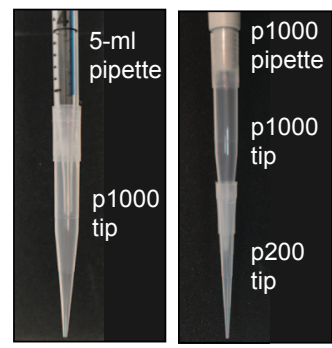
steps 3-4: clarification of the lysate steps 7-10: $\mathbf{1}^{\text {st }}$ polymerisation

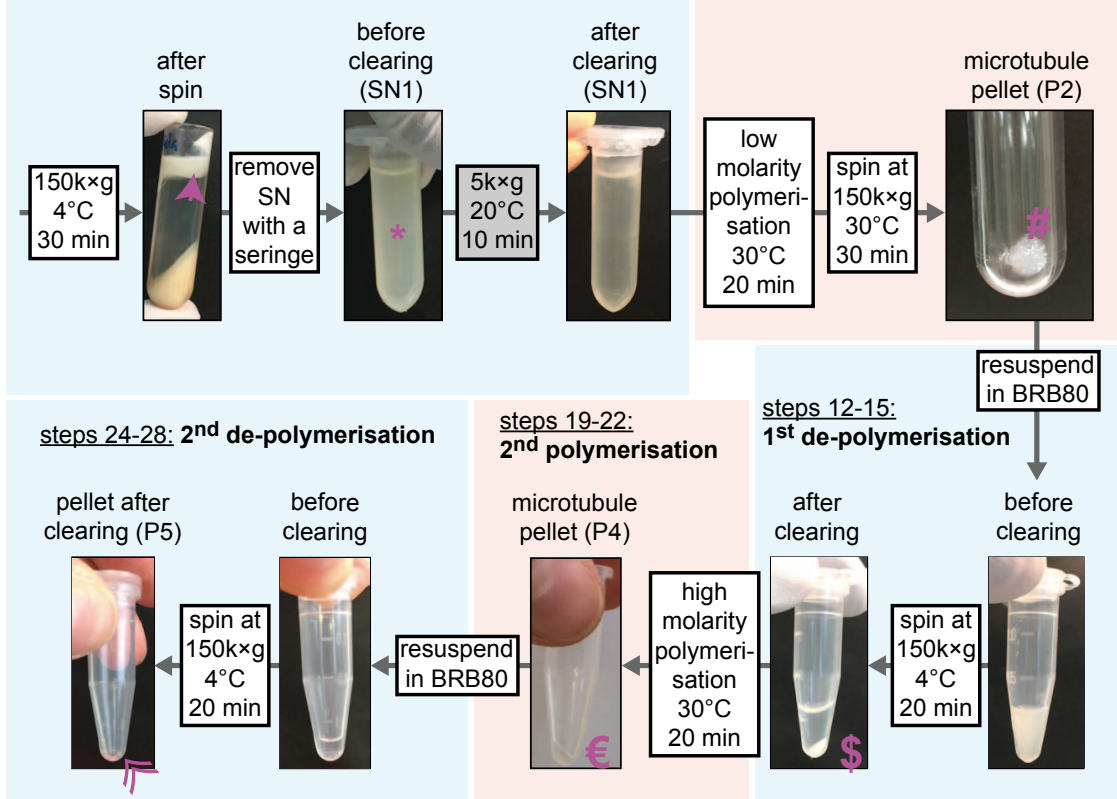


a

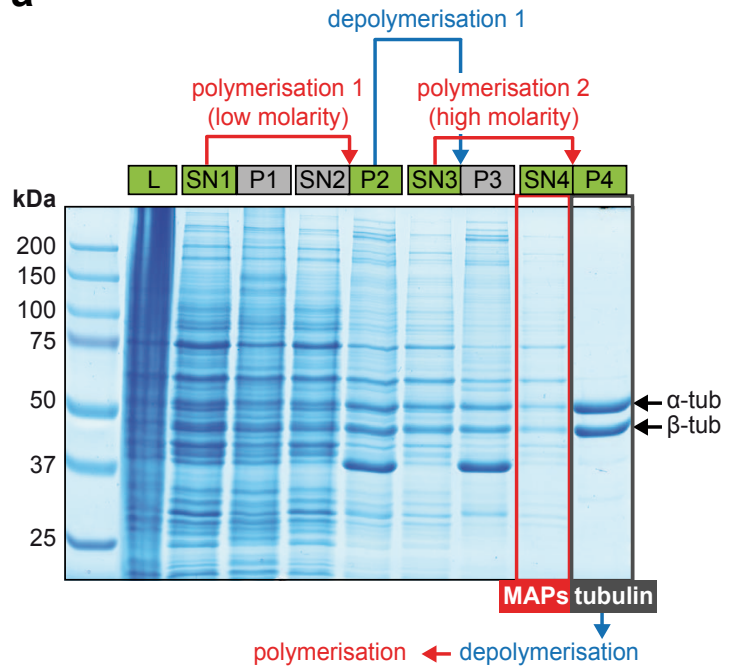

C

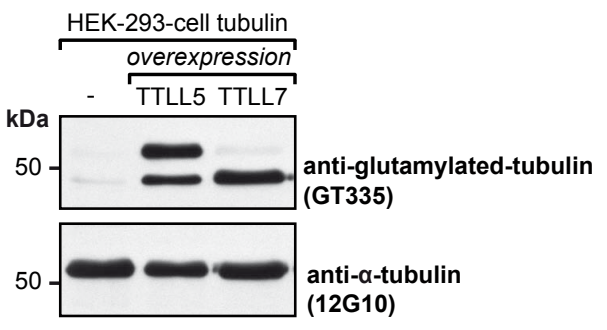

b

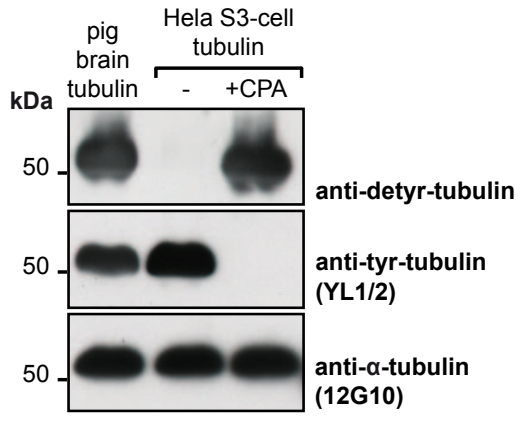

d

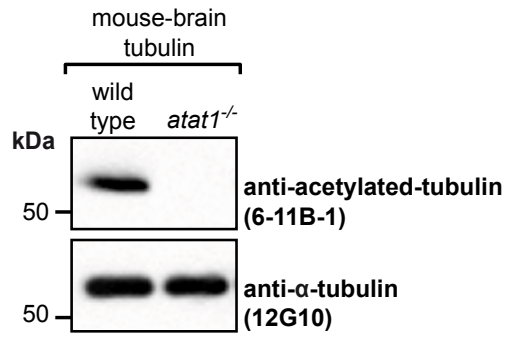

$\begin{aligned} & \text { wild } \\ & \text { type } t t l / 1^{-/}\end{aligned}-\begin{aligned} & \text { anti-polyglutamylated-tubulin } \\ & \text { (polyE) }\end{aligned}$

